\title{
NATO AND INTERNATIONAL CRIMES IN THE KOSOVO CAMPAIGN - CAN BILl CLINTON AND TONY BLAIR BE HELD CRIMINALLY LIABLE?
}

\author{
Peter James Niven*
}

This paper examines the international law doctrines of command responsibility and sovereign immunity with respect to the potential liability of Bill Clinton and Tony Blair for any war crimes committed during "Operation Just Cause" in Kosovo in 1999. The paper discusses some of the alleged crimes committed by NATO forces during the operation to establish a context for the analysis of their potential liability under the doctrine of command responsibility. This doctrine makes commanders criminally liable if they knew, or should have known, of crimes committed or about to be committed by their subordinates and the commander fails to take necessary and reasonable measures to prevent the crimes or punish the perpetrators. Even if Clinton and Blair could be held criminally liable under this doctrine any prosecution faces the hurdle of sovereign immunity attaching to them as a former Head of State and current Head of Government.

\section{INTRODUCTION}

The formation of the International Criminal Tribunal for the Former Yugoslavia (ICTY) and the International Criminal Tribunal for Rwanda (ICTR) ${ }^{1}$ has led to the first international judicial

* This paper was originally submitted in September 2001 for the LLB (Hons) Degree at Victoria University of Wellington, and the section on sovereign immunity has been updated to reflect the International Court of Justice decision in the Case Concerning the Arrest Warrant of 11 April 2000 (Democratic Republic of the Congo $v$ Belgium) (14 February 2002) ICJ <http://www.icj-cij.org/icjwww/idocket/iCOBE/ icobejudgment/icobe-ijudgment_20020214.pdf $>$ (last accessed 20 September 2002).

1 The International Criminal Tribunal for the Former Yugoslavia $<$ http://www.un.org/icty/index.html $>$ (last accessed 20 July 2001) [ICTY]; International Criminal Tribunal for Rwanda $<$ http://www.ictr.org/> (last accessed 10 June 2001) [ICTR]. The ICTY was created pursuant to the Security Council Resolution 827 of 25 May $1993<\mathrm{http} / / /$ www.un.org/icty/basic/statut/S-RES-827 93.htm> (last accessed 12 August 2001); the ICTR was created by the Security Council Resolution 955 of 8 November 1994 $<\mathrm{http}: / /$ www.ictr.org/ENGLISH/Resolutions/955e.htm > (last accessed 12 August 2001). Both tribunals were established under Chapter VII of the Charter of the United Nations [UN Charter] $<\mathrm{http}: / /$ www.unhcr.ch/html/menu3/b/ch-cont.htm> (last accessed 12 August 2001). 
proceedings against perpetrators of serious international crimes since the end of the Second World War. Since their formation, there has been further progress at the international level aimed at ending impunity for international criminals. The most important of these is the formation of the International Criminal Court (ICC), which came into being on 1 July $2002 .^{2}$ It currently has 139 signatories and has been ratified by 80 States. $^{3}$ New Zealand has ratified the Rome Statute of the International Criminal Court and has passed implementing legislation. ${ }^{4} \mathrm{~A}$ special court is in the process of formation in Sierra Leone to deal with the war crimes from that conflict, developed through cooperation between Sierra Leone and the United Nations. ${ }^{5}$ Talks have resumed between Cambodia and the United Nations aimed at establishing a tribunal to try those guilty of serious crimes during Cambodia's civil war. ${ }^{6}$ The failure of Indonesia to adequately prosecute those responsible for the crimes in East Timor in 1999 is also leading to calls for the formation of a tribunal for the world's newest nation. ${ }^{7}$

This renewed international effort to bring the perpetrators of serious international crimes to justice is the concern of all States. The ICTY and ICTR were established under Chapter VII of the United Nations Charter, so all member States are under an international obligation to cooperate with them. ${ }^{8}$ States-parties to the ICC will be under international obligations, defined in the ICC Statute, to cooperate with that court once it is established. Under some international treaties and conventions, including the ICC Statute, States-parties are required to establish domestic jurisdiction

2 Under art 126 of the Rome Statute of the International Criminal Court, 17 July 1998 (1998) 37 ILM 998 [ICC Statute].

3 See <http://untreaty.un.org/ENGLISH/bible/englishinternetbible/partI/chapterXVIII/treaty10.asp > (last accessed 18 September 2002).

4 The International Crimes and International Criminal Court Act 2000.

5 UN News Service Press Release SG/A/813 AFR/444 "Appointments to Sierra Leone Special Court" (26 July 2002) <http://www.un.org/News/Press/docs/2002/sga813.doc.htm> (last accessed 18 September 2002); Sierra Leone's implementing legislation for the special court, the implementing agreement and statute of the court are all available on the "No Peace Without Justice" Website $<$ http://www.specialcourt.org/documents/index $1 . h t m>$ (last accessed 18 September 2002).

6 BBC News Online "Cambodia to Resume UN Tribunal Talks" (22 August 2002) <http://news.bbc.co.uk/1/hi/world/asia-pacific/2209063.stm> (last accessed 18 September 2002).

7 BBC News Online "East Timor Verdicts Provoke Outrage" (15 Aug 2002) $<$ http://news.bbc.co.uk/1/hi/world/asia-pacific/2195196.stm> (last accessed 03 September 2002).

8 The United Nations Security Council (UNSC) resolutions establishing the ICTY were made under Chapter VII of the United Nations Charter, $<$ http://www.unhcr.ch/html/menu3/b/ch-cont.htm>, which empowers the UNSC to make resolutions that are binding on all member states of the UN. 
over offenders. ${ }^{9}$ These developments are positive steps towards ending impunity for serious international criminals.

The conflict in Afghanistan, the conflict in the Democratic Republic of the Congo, the war with Iraq, the recent violence and allegations of war crimes in Israel, all highlight starkly the need to ensure there is no impunity for offenders against international humanitarian law. The prevention and suppression of war crimes in particular is contingent on commanders and civilian leaders ensuring that legal standards are adhered to, and enforced when they are not adhered to. International law recognises this need through the imposition of a duty on commanders to prevent or to punish international crimes in their subordinates. This paper will examine this doctrine of command responsibility in the context of the NATO Campaign in Kosovo in 1999, Operation Allied Force. There have been allegations that civilian leaders of NATO are criminally responsible for the commission of serious international crimes, including genocide, crimes against humanity, and war crimes in Kosovo. The international developments in this area make it an interesting exercise to consider whether Tony Blair and Bill Clinton could be held criminally liable under international law for any international crimes that may have been committed by NATO during Operation Allied Force.

The issues of international law that this scenario raises revolve principally around two international law doctrines: the doctrine of command responsibility and the doctrine of sovereign immunity. This is due to the fact that, with the possible exception of the crime of aggression, neither Clinton nor Blair could have been the actual perpetrator of any offence. Neither leader actually dropped any bombs or launched any missiles that caused civilian deaths. Any criminal liability that the two may be exposed to will be via the doctrine of command responsibility, for either directly ordering or planning acts that were international crimes, or through an omission-based liability for failing to prevent or punish any crimes committed by subordinates under their effective control. Even if criminal liability is established via command responsibility both men enjoy a degree of immunity by virtue of the doctrine of sovereign immunity, and Part VI will seek to establish how this doctrine interrelates to the notion of individual criminal responsibility at international law.

This paper will first examine the allegations made against NATO to determine whether there a prima facie case can be made out. It will then determine the content of the doctrine of command responsibility at customary international law, and how it pertains to civilian leaders. The doctrine can then be applied to Clinton and Blair, with respect to some of the alleged criminal incidents from the Kosovo campaign. Finally the impact of the doctrine of sovereign immunity on their potential criminal liability under the doctrine of command responsibility will be considered.

9 For example, see: Convention against Torture and Other Cruel, Inhuman or Degrading Treatment or Punishment (10 December 1984) 1465 UNTS 85 Art 5 [Torture Convention 1984]; Convention on the Prevention and Punishment of the Crime of Genocide (9 December 1948) 78 UNTS 277, Art 5 [Genocide Convention 1948]. 
This paper will not examine the issue of whether NATO, and the NATO leaders who made the decision to use force, may have committed the crime of aggression. It is worth noting that the content and scope of the crime of aggression is the subject of some controversy in the international community, ${ }^{10}$ and that politicians and international lawyers alike dispute the legality of NATO's intervention in Kosovo. ${ }^{11}$ The Federal Republic of Yugoslavia (FRY) has brought cases before the International Court of Justice (ICJ) against the participating NATO countries. ${ }^{12}$ If the ICJ makes a decision on the merits of these cases that may provide some needed clarification of where international law stands on the use of force for humanitarian intervention.

II INTERNATIONAL CRIMES AND NATO: GENOCIDE, WAR CRIMES AND CRIMES AGAINST HUMANITY?

\section{A The Charges Against NATO}

This section examines the allegations that have been made against NATO, and whether there is a prima facie case to answer on these allegations. There have been a number of allegations ranging from an accusation of genocide through to allegations of war crimes relating to individual incidents. the claims of genocide and crimes against humanity are not sustainable, as the legal threshold requirements are not met, and it is only for some of the more problematic incidents that a prima facie case can be made out for a war crime having been committed. It is on the basis of these incidents that we can assess Clinton and Blair's possible criminal liability.

10 The signatories of the Rome Statute of the International Criminal Court were unable to agree on the definition of the crime of aggression and its inclusion in the Statute, with the result that it was excluded until a review of the Statute seven years after entry into force: Rome Statute of the International Criminal Court (17 July 1998) 37 ILM 998, arts 5(2), 121 and 123.

11 For example, Sergey Egorov, Professor of International Law at the Diplomatic Academy of the Ministry of Foreign Affairs in Moscow, rejects any right of humanitarian intervention without authorisation by the Security Council under Chapter VII of the Charter: Sergey Alexeyevich Egorov "The Kosovo Crisis and the Law of Armed Conflicts" (31 March 2000) International Review of the Red Cross No 837, 183 $<$ http://www.icrc.org/icrceng.nsf/4dc394db5b54f3fa4125673900241f2f/002b6188e758f33b412568d40028cf 8d?OpenDocument> (last accessed 20 July 2001); Law and Right: When They Don't Fit Together Economist (3 April 1999) $19-20$.

12 Legality of Use of Force (Yugoslavia v Belgium) (Yugoslavia v Canada) (Yugoslavia v France) (Yugoslavia $v$ Germany) (Yugoslavia v Italy) (Yugoslavia v Netherlands) (Yugoslavia v Portugal) (Yugoslavia v United Kingdom). Any substantive judgment on the merits of the case is a long way off, with the ICJ recently extending by another year the time-limits originally fixed for the filing by Yugoslavia of written statements of its observations and submissions on the preliminary objections raised by the eight respondent States to 7 April 2003: ICJ Press Release 2002/10 22 March $2002<$ http://www.icj-cij.org/icjwww/ipresscom/ ipress2002/ipresscom2002-10_yugo_20020322.htm> (last accessed 18 September 2002). 
There have been allegations from a variety of sources that NATO committed a number of war crimes, genocide and crimes against humanity during the Kosovo war. ${ }^{13}$ Amnesty International produced a report, ${ }^{14}$ based on the work done by Human Rights Watch ${ }^{15}$ and allegations by the FRY authorities, which alleged war crimes relating to a number of specific attacks on civilians. The Office of the Tribunal Prosecutor (OTP) for the ICTY investigated these claims and produced a report that concluded there was insufficient evidence to proceed with any prosecutions for war crimes. ${ }^{16}$ The OTP Final Report only considered allegations of war crimes against NATO. The wider allegations advanced against NATO, including allegations of genocide and crimes against humanity, were not considered. However, neither of these allegations can be sustained, as the threshold requirements for these offences are not met.

\section{B Genocide}

Genocide involves specified acts "committed with the intent to destroy, in whole or in part, a national, ethnical, racial or religious group". ${ }^{17}$ There is no evidence to suggest that NATO had any such intent, in fact the evidence is that they acted to prevent what they believed to be widespread persecution and murder by the forces of FRY of Kosovar Albanians based on their racial and religious identity. ${ }^{18}$ There is sufficient evidence that FRY was engaged in such acts that Milosevic

13 For example, Tania Voon "Pointing the Finger: Civilian Casualties of NATO Bombing in the Kosovo Conflict (2001) 16 Am U Int'l Rev 1083; see also the "indictment" drawn up by the former US Attorney General Ramsey Clark, naming both Clinton and Blair along with numerous others, charging them with various crimes on behalf of the International Action Centre (IAC) $<$ http://www.iacenter.org/ warcrime/indictmt.htm $>$ (last accessed 21 August 2001).

14 NATO/Federal Republic of Yugoslavia: "'Collateral Damage' or Unlawful Killings? Violations of the Laws of War by NATO during Operation Allied Force" (EUR 70/018/2000) [Amnesty Report] $<$ http://web.amnesty.org/ai.nsf/Index/EUR700182000> (last accessed on 1 July 2001).

15 Civilian Deaths in the NATO Air Campaign, February $2000<$ http://www.hrw.org/reports/2000/nato/ index.htm $>$ (last accessed on 1 July 2001).

16 Final Report to the Prosecutor by the Committee Established to Review the NATO Bombing Campaign Against the Federal Republic of Yugoslavia, para 90 [OTP Final Report] <http://www.un.org/ icty/pressreal/nato061300.htm $>$ (last accessed on 1 July 2001).

17 Convention on the Prevention and Punishment of the Crime of Genocide (9 December 1948) 78 UNTS 277, Art 2.

18 NATO Secretary General, Dr Javier Solana at NATO Press Conference 25 March 1999 (after the first night of combat operations): "Let me reiterate we are determined to continue until we have achieved our objectives: to halt the violence and to stop further humanitarian catastrophe. Let me emphasise once again that we have no quarrel with the people of Yugoslavia. Our actions are directed against the repressive policies of the Yugoslav government, which is refusing to respect civilized norms of behaviour in this Europe at the end of the 20th century." NATO Press Conference (25 March 1999) < http://www.nato.int/ kosovo/press/p990325a.htm> (last accessed 18 September 2002). 
is currently on trial at the ICTY for alleged crimes including forced deportation, murder and persecution in Kosovo. ${ }^{19}$

\section{Crimes Against Humanity}

The ICTY has conducted the first prosecutions for crimes against humanity by an international tribunal since the proceedings at the end of the Second World War. Crimes against humanity are included in the ICTY Statute at Article 5. ${ }^{20}$ The ICTY in the Tadic Case ${ }^{21}$ has interpreted Article 5 of its Statute so that in order to constitute a crime against humanity, acts must occur within the context of an armed conflict; be linked geographically or temporally with that conflict; the act must not be unrelated to the conflict, such as for personal motives; and the act must occur as part of a widespread or systematic attack on a civilian population. ${ }^{22}$ The Trial Chamber was of the opinion that the requirement for an armed conflict in the ICTY Statute narrowed the customary international law position, ${ }^{23}$ as consideration of other international instruments and jurisprudence illustrates that in customary law there is no requirement for "an armed conflict."

In the ICC Statute, crimes against humanity must be committed in the context of a "wide-spread or systematic attack directed against any civilian population, with knowledge of the attack", ${ }^{24}$ though the attack does not have to be military in nature, and therefore presumably there is no need for an armed conflict as a contextual requirement. ${ }^{25}$ The ICTR Statute does not have a requirement

19 The Prosecutor v Slobodan Milosevic, Milan Milutinovic, Nikola Sainovic, Dragoljub Ojdanic, Vlajko Stojiljkovic IT-99-37-PT, Second Amended Indictment (16 October 2001) <http://www.un.org/ icty/indictment/english/mil-2ai011029e.htm> (last accessed 16 September 2002).

20 Statute of the International Criminal Tribunal for the Former Yugoslavia, as amended 30 November 2000 by Resolution 1329 [ICTY Statute] <http://www.un.org/icty/basic/statut/stat2000_con.htm> (last accessed 16 August 2001).

21 Prosecutor v Dusko Tadic aka "Dule" Trial Chamber Judgment IT-94-1 (ICTY, 7 May 1997) [Tadic] $<$ http://www.un.org/icty/tadic/trialc2/judgment/index.htm $>$ (last accessed 8 July 2001). This judgment was the first by the ICTY, and the "the first determination of individual guilt or innocence in connection with serious violations of international humanitarian law by an international tribunal .... The international military tribunals at Nürnberg and Tokyo ... were multinational in nature, representing only part of the world community" Tadic, above, para 1. Consequently, it was the first judicial determination of the legal tests for crimes against humanity and the development of international law since the trials following the Second World War.

22 Tadic, above, paras 618-659.

23 Tadic, above, para 627.

24 Under art 126 of the Rome Statute of the International Criminal Court, 17 July 1998 (1998) 37 ILM 998 , Art 7.

25 Report of the Preparatory Commission for the International Criminal Court, Addendum Part II, Finalized draft text of the Elements of Crimes (2 November 2000) PCNICC/2000/1/Add.2, 9 [ICC Draft Elements of Crimes] <http://www.un.org/law/icc/statute/elements/english/1_add2e.pdf\#pagemode=bookmarks $>$ (last accessed 15 August 2001). 
in its Article 3 for the existence of an armed conflict. ${ }^{26}$ The International Law Commission's (ILC) $)^{27}$ Draft Code of Crimes Against the Peace and Security of Mankind (ILC Draft Code) outlines the contextual requirements for crimes against humanity in Article 18, as "committed in a systematic manner or on a large scale and instigated or directed by a Government or by any organisation or group." 28 The ILC in its commentary rejects the requirement for a connection to an armed conflict or war crimes for the proscribed acts to constitute crimes against humanity. ${ }^{29}$ Having regard to the jurisprudence of the ICTY, ${ }^{30}$ the ICTR and the various international instruments discussed above, the contextual requirements for crimes against humanity are that the act was part of a widespread and systematic attack on a civilian population, and that the perpetrator knew that the act was part of that attack.

The evidence of the nature and intent of NATO operations does not support any claim that they constituted a systematic or widespread attack on a civilian population. As the OTP Final Report notes, out of some 10,484 strike sorties by NATO aircraft, releasing 23,614 air munitions, only around 90 incidents have been documented that involved civilian deaths $(0.9 \%$ of all strikes missions). ${ }^{31}$ The first alternative requirement, a systematic attack, means attacks "pursuant to a preconceived plan or policy". ${ }^{32}$ The contextual requirement of an "attack on a civilian population" is understood as attacks as part of a State or organisational policy of attack on that civilian

26 "The International Tribunal for Rwanda shall have the power to prosecute persons responsible for the following crimes when committed as part of a widespread or systematic attack against any civilian population on national, political, ethnic, racial or religious grounds ..." Statute of the International Criminal Tribunal for Rwanda, Art 3 [ICTR Statute] <http://www.ictr.org/ENGLISH/basicdocs/statute.html $>$ (last accessed 10 August 2001).

27 The International Law Commission was established by the General Assembly in 1947 to promote the progressive development of international law and its codification (Article 13(1) of the Charter of the United Nations) $<$ http://www.un.org/law/ilc/introfra.htm $>$ (last accessed 9 August 2001).

28 Draft Code of Crimes against the Peace and Security of Mankind 1996 Art 18 [ILC Draft Code] $<$ http://www.un.org/law/ilc/texts/dcodefra.htm> (last accessed 1 April 2001). The Draft Code was provisionally adopted in 1988: Regina $v$ Bartle and the Commissioner of Police for the Metropolis and Others, Ex Parte Pinochet; Regina $v$ Evans and Another and the Commissioner of Police for the Metropolis and Others, Ex Parte Pinochet [1999] UKHL 17 Lord Goff, paras 83 - 84 [Pinochet].

29 Report of the International Law Commission on the work of its forty-eighth session (6 May-26 July 1996) General Assembly Official Records - Fifty-first Session Supplement No 10 (A/51/10), Chapter II, commentary on Art 18, para 6 [ILC Report 1996] <http://www.un.org/law/ilc/reports/1996/96repfra.htm> (last accessed 15 August 2001).

30 This acknowledges that its requirement for an "armed conflict", dictated by the wording of its Statute, narrows the customary international law position, Prosecutor v Dusko Tadic aka "Dule" Trial Chamber Judgment IT-94-1 (ICTY, 7 May 1997).

31 Final Report to the Prosecutor by the Committee Established to Review the NATO Bombing Campaign Against the Federal Republic of Yugoslavia, para 54.

32 Report of the International Law Commission on the work of its forty-eighth session, above, para 3. 
population. ${ }^{33}$ While a few individual cases might involve allegations of targeting of civilians, there is no evidence that NATO had a policy or plan to target civilians. ${ }^{34}$ In fact all the evidence, including the statistics quoted above, tend to establish that NATO policy and planning was predicated on avoiding civilian casualties as far as was possible. The individual incidents alleged by the FRY to constitute crimes against humanity do not occur in the necessary context, and therefore do not meet the threshold requirement.

\section{War Crimes}

The last category that the incidents may fall under is that of war crimes, violations by NATO of the laws and customs of war. These are codified to a certain extent in international treaties and instruments such as the Geneva Conventions, and their protocols, and the Hague Conventions. ${ }^{35}$ The laws and customs of war also form part of international customary law. In the context of NATO's attack on the FRY, the threshold requirement of an international conflict is met for the full application of all of the laws and customs of war.

There have been a number of allegations of war crimes made against NATO, many allegations relating to specific identified incidents. The presence of members of the international press in Kosovo and Serbia, and the technology of NATO aircraft meant that the details of specific incidents were often available within days, sometimes hours, of the attacks. As discussed above the OTP final report found insufficient evidence of any war crimes to justify proceeding with further investigation. ${ }^{36}$

The OTP final report considers general accusations in relation to over 24 incidents, and then considers five particular incidents that "were the most problematic". ${ }^{37}$ This paper will consider the possible liability for Clinton and Blair via the doctrine of command responsibility for three of these "problematic" incidents.

33 Report of the Preparatory Commission for the International Criminal Court, Addendum Part II, Finalized draft text of the Elements of Crimes (2 November 2000) PCNICC/2000/1/Add.2, 9.

34 Some of these problematic individual cases will be discussed below in connection with the allegations of war crimes.

35 The four Geneva Conventions of 1949 are included as schedules to the Geneva Conventions Act 1958 and their two Additional Protocols are included as schedules to the Geneva Conventions Amendment Act 1987. Both the Geneva Conventions, their Protocols and the Hague Conventions and annexed regulations are available on-line at the University of Minnesota Human Rights Library <http://www1.umn.edu/humanrts/ instree/auoy.htm $>$ (last accessed 19 September 2002).

36 Final Report to the Prosecutor by the Committee Established to Review the NATO Bombing Campaign Against the Federal Republic of Yugoslavia [OTP Final Report], para 90.

37 OTP Final Report, above, para 57. 
As the focus of this paper is on the liability of Clinton and Blair via the doctrine of command responsibility, this paper will not examine the lawfulness of the various incidents alleged to be violations of the laws and customs of war. Instead three specific incidents will be assumed to be prima facie war crimes for the purposes of the discussion of command responsibility and sovereign immunity: ${ }^{38}$

(1) The attack on a civilian passenger train at the Grdelica Gorge on 12 April 1999. ${ }^{39}$ A NATO aircraft fired two missiles at a bridge, hitting a train and killing as many as 12 civilians. The second missile was fired after the train had been hit and identified by the pilot, aimed at a different part of the smoke-obscured bridge. The train had slid forward and was hit again. This will be assumed to be a grave breach of the First Protocol, Article $85(3)(b),{ }^{40}$ characterised as an "indiscriminate" attack. ${ }^{41}$

(2) The second incident is the attack on the convoys at Djakovica on 14 April 1999. ${ }^{42}$ NATO aircraft bombed two separate columns of refugees after they misidentified them as military convoys. As many as 70 civilians may have been killed and over 100 wounded.

38 Despite the OTP findings that there was insufficient evidence to warrant further investigation over these incidents there is still opinion that these incidents did in fact constitute breaches of the laws of war. For example, Tania Voon "Pointing the Finger: Civilian Casualties of NATO Bombing in the Kosovo Conflict (2001) 16 Am U Int'l Rev 1083; A "tribunal" convened by the IAC, found NATO "guilty" of a number of war crimes at a mock trial held in New York on 10 June 2000, IAC "War Crimes Tribunal Finds US and NATO Guilty" (6 December 2000) <http://www.iacenter.org/warcrime/wct2000.htm> (last accessed 21 August 2001).

39 OTP Final Report, above, paras 58-62; NATO/Federal Republic of Yugoslavia: "'Collateral Damage' or Unlawful Killings? Violations of the Laws of War by NATO during Operation Allied Force" (EUR 70/018/2000) [Amnesty Report] <http://web.amnesty.org/ai.nsf/Index/EUR700182000> (last accessed on 1 July 2001) s 5.1 .

40 Article $8 \mathrm{~s}$ (3) The following acts shall be regarded as grave breaches, when committed wilfully, in violation of the relevant provisions of this Protocol, and causing death...(b) launching an indiscriminate attack affecting the civilian population or civilian objects in the knowledge that such attack will cause excessive loss of life, injury to civilians or damage to civilian objects..." Protocol Additional to the Geneva Conventions of 12 August 1949, and Relating to the Protection of Victims of International Armed Conflicts (Protocol I) (June 8 1977) 1125 UNTS 3 Art 85 [First Protocol].

41 First Protocol, above, Art 51(4)-51(5) defines an "indiscriminate" attack. Arguably these attacks, in failing to comply with the precautionary measures mandated under Art 57, may have shaded into indiscriminate attacks either in terms of Art 51(4)(a) or 51(4)(c).

42 Final Report to the Prosecutor by the Committee Established to Review the NATO Bombing Campaign Against the Federal Republic of Yugoslavia, paras 63-70 [OTP Final Report]; NATO/Federal Republic of Yugoslavia: "'Collateral Damage' or Unlawful Killings? Violations of the Laws of War by NATO during Operation Allied Force" (EUR 70/018/2000) [Amnesty Report] <http://web.amnesty.org/ai.nsf/Index/ EUR700182000> (last accessed on 1 July 2001) s 5.2. 
This will be assumed to be a grave breach of the First Protocol, Article 85(3)(b), characterised as an "indiscriminate" attack. $^{43}$

(3) The last incident is the attack on Serbian State Television and Radio (RTS) on 23 April 1999. ${ }^{44}$ At least 16 civilians were killed and another 16 wounded in this attack. This could be a violation of either the First Protocol, Article 85(3)(a), ${ }^{45}$ making the civilian population the object of attack, if RTS was not a military objective, ${ }^{46}$ or the First Protocol, Article 85(3)(b), if the attack was characterised as an "indiscriminate" attack.

\section{THE DOCTRINE OF COMMAND RESPONSIBILITY}

Assuming that the three incidents outlined above are prima facie war crimes, can criminal liability be attributed to Clinton and Blair? In each instance the actual attack was conducted by unidentified coalition aircraft, operating under orders from their immediate commanders, orders passed through the chain of command from NATO command. As a former Head of State and a current Head of Government respectively, the question is whether they can be held criminally liable through the doctrine of command responsibility for these incidents.

The first formal recognition of a duty for military commanders to prevent and punish violations of the laws of war by their subordinates is arguably in the 1907 Hague Conventions. ${ }^{47}$ The idea that military commanders, and even civilian leaders, might be held criminally liable for violations of the laws and customs of war by their subordinates was canvassed as early as the close of World War One: ${ }^{48}$

43 OTP Final Report, above.

44 OTP Final Report, above, paras 71 - 79; Amnesty Report, above, s 5.3.

45 Article 85 (3) "the following acts shall be regarded as grave breaches, when committed wilfully, in violation of the relevant provisions of this Protocol, and causing death...(a) making the civilian population or individual civilians the object of attack", First Protocol, above, Art 85 .

46 Military Objects are defined in the First Protocol, "(3) The following acts shall be regarded as grave breaches, when committed wilfully, in violation of the relevant provisions of this Protocol, and causing death...(b) launching an indiscriminate attack affecting the civilian population or civilian objects in the knowledge that such attack will cause excessive loss of life, injury to civilians or damage to civilian objects..." First Protocol, above, Art 52(30).

47 "Undoubtedly ... the Hague Conventions IV (1907) 5 and X (1907) 6 created affirmative command duties in relation to the conduct of subordinate persons, establishing the doctrine of 'command responsibility'": Ilias Bantekas "The Contemporary Law of Superior Responsibility" 93 AJIL 573, 573; Andrew D Mitchell "Failure to Halt, Prevent or Punish: The Doctrine of Command Responsibility for War Crimes" 22 Sydney L Rev 381, $383-384$.

48 Commission on the Responsibility of the Authors of the War and on the Enforcement of Penalties, Report Presented to the Preliminary Peace Conference (1920) 14 AJIL 95, 121 [Commission on Responsibility Report]. 
There remain, however, a number of charges ... against all authorities, civil or military, belonging to enemy countries, however high their position may have been, without distinction of rank, including the heads of states, who ordered, or with knowledge thereof and with power to intervene, abstained from preventing or taking measures to prevent, putting an end to or repressing, violations of the laws or customs of war..

The recommended "high tribunal" for the trial of these and other charges did not eventuate. ${ }^{49}$ It was not until the trials of war criminals following the Second World War that this doctrine of command responsibility was applied. The Charter of the Nürnberg Tribunal did not fully incorporate the doctrine of command responsibility, ${ }^{50}$ and proceeded only on the basis of direct liability for the highest Nazi officials. It was the Tokyo Tribunal, in the Yamashita case, ${ }^{51}$ that first convicted a superior for his responsibility in failing to prevent or punish crimes of his subordinates. Subsequent proceedings in Europe against German commanders and officials also proceeded on the basis of this indirect liability. ${ }^{52}$ Following the trials in Nürnberg and Tokyo, it was not immediately clear to contemporaries what the full scope of the doctrine was in terms of responsibility for failure by superiors to prevent or punish war crimes. ${ }^{53}$ The introduction into the 1977 First Protocol to the Geneva Conventions of duties on commanders were not only "... uncontested during the deliberations for the adoption of Geneva Protocol I, but both Articles 86 and 87 were held to be in conformity with pre-existing law." 54

49 Commission on Responsibility Report, above, 122-123.

50 Art 6 of the Charter provides that "Leaders, organisers, instigators and accomplices participating in the formulation or execution of a common plan or conspiracy to commit any of the foregoing crimes are responsible for all acts performed by any persons in execution of such plan." Agreement for the Prosecution and Punishment of the Major War Criminals of the European Axis, and Charter of the International Military Tribunal London, (8 August 1945) [Nürnberg Charter] <http://www.icrc.org/ihl.nsf/ 385ec082b509e76c41256739003e636d/59e5a3f396d98cc3c125641e00405ea7?OpenDocument> (last accessed 9 August 2001). This incorporates the first limb of command responsibility as discussed below, liability for positive acts, but makes no mention of liability for omission to prevent or punish, or indirect liability.

51 United Nations War Crimes Commission, Law Reports of Trials of War Criminals 1 (1948). Following conviction Yamashita appealed to the United States Supreme Court, and the doctrine of command responsibility is addressed in that judgment: $J v$ K Yamashita (1946) 327 US 1.

52 Ilias Bantekas "The Contemporary Law of Superior Responsibility" 93 AJIL 573, 574; Greg R Vetter "Command Responsibility of Non-Military Superiors in the International Criminal Court" (2000) 25 Yale J Int'1 L 89, 95.

53 "No clear rule has emerged as to the extent to which a civil or military superior can be convicted of failing to prevent crimes committed by persons under his authority", G Brand "War Crimes Trials and the Laws of War" (1949) 26 BYIL 414, 424.

54 Bantekas, above, 576-577. 
The establishment of the International Criminal Tribunal for Yugoslavia (ICTY) in 1992 was the first opportunity since the post-World War Two trials for an international tribunal to examine the doctrine of command responsibility. International law had developed since the Nürnberg and Tokyo trials, with the entry into force of the various Geneva Conventions and Protocols, and the development of international humanitarian law. The doctrine of command responsibility, as regards indirect responsibility, ${ }^{55}$ is articulated at Article 7(3) of the ICTY Statute: ${ }^{.6}$

[t]he fact that any of the acts referred to in articles 2 to 5 of the present Statute was committed by a subordinate does not relieve his superior of criminal responsibility if he knew or had reason to know that the subordinate was about to commit such acts or had done so and the superior failed to take the necessary and reasonable measures to prevent such acts or to punish the perpetrators thereof.

In interpreting Article 7(3) the ICTY had to have regard to the international customary law existing at the time of the offences, to avoid compromising the nullum crimen sine lege principle. ${ }^{57}$ The Tribunal considers its interpretation of Article 7(3) to be consistent with the position in customary international law at the time the offences were committed, ${ }^{58}$ having regard to the World War Two jurisprudence from the Nürnberg and Tokyo trials, ${ }^{59}$ the relevant articles from the First

55 Direct liability is captured under Article 7(1): "A person who planned, instigated, ordered, committed or otherwise aided and abetted in the planning, preparation or execution of a crime referred to in articles 2 to 5 of the present statute, shall be individually responsible for the crime". Statute of the International Criminal Tribunal for the Former Yugoslavia, as amended 30 November 2000 by Resolution 1329 [ICTY Statute] $<$ http://www.un.org/icty/basic/statut/stat2000_con.htm> (last accessed 16 August 2001).

56 Statute of the International Criminal Tribunal for the Former Yugoslavia, as amended 30 November 2000 by Resolution 1329 [ICTY Statute] <http://www.un.org/icty/basic/statut/stat2000_con.htm> (last accessed 16 August 2001). Article 7(3); note the ICTR has an identical provision, Statute of the International Criminal Tribunal for Rwanda, Art 3 [ICTR Statute] <http://www.ictr.org/ENGLISH/basicdocs/ statute.html $>$ (last accessed 10 August 2001) Art 6(3).

57 "The implication of these explanations is that the Security Council, not being a legislative body, cannot create offences. It therefore vests in the Tribunal the exercise of jurisdiction in respect of offences already recognised in international humanitarian law. The Statute does not create substantive law, but provides a forum and framework for the enforcement of existing international humanitarian law" Prosecutor v Zejnil Delalic, Zdravko Mucic (aka "Pavo"), Hazim Delic and Esad Landžo (aka "Zenga") ("Celebici" Case) Judgment IT-96-21 (ICTY, 16 November 1998) para 417 [Celebici Case Trial Judgment] $<$ http://www.un.org/icty/celebici/trialc2/judgment/index.htm> (last accessed 3 July 2001); this principle is enshrined in the ICC Statute, above, Art 22.

58 The ICTY has jurisdiction over offences committed within the territories of the Former Yugoslavia from 1 January 1991, ICTY Statute, above, Art 1. The ICTY's consideration of international law is grounded in this time period, and subsequent developments, such as the emergence of the ICC, may effect changes on the content of customary international law in the future. See below para 31.

59 Some of the main cases are: Yamashita United Nations War Crimes Commission, Law Reports of Trials of War Criminals 1 (1948) following conviction Yamashita appealed to the US Supreme Court, and the doctrine of command responsibility is addressed in that judgment: In re Yamashita (1946) 327 US 1; United States $v$ Karl Brandt et al Vol IV Trials of War Criminals before the Nürnberg Military Tribunals under 
Protocol, ${ }^{60}$ the ICC Statute ${ }^{61}$ and the ILC Draft Code. ${ }^{62}$ As a result its jurisprudence is of significance for other international tribunals or courts (the ICTR, and the ICC) and also for domestic courts dealing with offences under domestic jurisdiction. ${ }^{63}$

The ICTY considered the doctrine of command responsibility in a number of cases, in particular in the Celebici Case Judgments by Trial Chamber II and the Appeals Chamber. ${ }^{64}$ In this case, four men were charged with various crimes committed in the Celebici prison camp, located in central Bosnia. Of the four Zdravko Mucic and Zejnil Delalic were charged with criminal liability as superiors for failing to prevent or punish the crimes of their subordinates, pursuant to Article 7(3) of the ICTY Statute. Delalic was acquitted on this count, but Mucic was found guilty. This case was

Control Council Law No 10 (US Govt Printing Office: Washington 1950) (hereafter "TWC"); United States $v$ Wilhelm List et al Vol XI TWC; United States $v$ Wilhelm Von Leeb et al Vol XI TWC; United States v Soemu Toyoda Official Transcript of Record of Trial [Toyoda]; Trial of Friederich Flick et al Vol VI TWC [Flick]; Government Commissioner v Roechling 14 TWC [Roechling].

60 Protocol Additional to the Geneva Conventions of 12 August 1949, and Relating to the Protection of Victims of International Armed Conflicts (Protocol I) (June 8 1977) 1125 UNTS 3 [First Protocol] Arts 86 and 87 .

61 Under article 126 of the Rome Statute of the International Criminal Court, 17 July 1998 (1998) 37 ILM 998 [ICC Statute] Art 28.

62 Draft Code of Crimes against the Peace and Security of Mankind 1996 Art 18 [ILC Draft Code] $<$ http://www.un.org/law/ilc/texts/dcodefra.htm> (last accessed 1 April 2001) Art 6.

63 The Prosecutor of the ICTY has allowed some cases within the jurisdiction of the Tribunal to proceed in domestic courts, Sean D Murphy "Developments in International Criminal Law: Progress and Jurisprudence of the International Tribunal for the Former Yugoslavia" (1999) 93 AJIL 57, 64 - 65. On a more general note, the development of jurisprudence in the area of war crimes and crimes against humanity by the International Tribunals will hopefully help domestic courts avoid the sort of mistaken jurisprudence exemplified by $R v$ Finta [1994] 1 SCR 701. The Canadian Supreme Court read in to the actus reus and mens rea requirements for Canada's domestic war crimes legislation a number of extra elements not founded in international custom that will make prosecution in most cases virtually impossible: Irwin Cotter "Regina v Finta, Canadian Supreme Court War Crimes Decision" 90 AJIL 461.

64 Celebici Case Trial Judgment, above, paras 330 - 400; Prosecutor v Zejnil Delalic, Zdravko Mucic (aka "Pavo"), Hazim Delic and Esad Landžo (aka "Zenga") ("Celebici" Case) Judgment IT-96-21 (ICTY, 20 February 2001) paras 182-314 [Celebici Case Appeal Judgment] <http://www.un.org/icty/celebici/appeal/ judgment/index.htm> (last accessed 3 July 2001); Vetter is of the opinion that "... it is likely that the best evidence of customary international law for command responsibility is the Celebici case because of its thorough treatment of the doctrine", Greg R Vetter, "Command Responsibility of Non-Military Superiors in the International Criminal Court" (2000) 25 Yale J Int'l L 89, 111. The Celebici formulation of the doctrine of command responsibility has not gone un-criticised. Ching is of the opinion that the Celebici formulation is not perfect as "... it has the potential danger of creating extensive liability for an especially poor or dull commander", Ann B Ching "COMMENT: Evolution of the Command Responsibility Doctrine in Light of the Celebici Decision of the International Criminal Tribunal for the Former Yugoslavia" 25 NCJ Int'l Law \& Com Reg 167, 204. On the other hand, Bantekas is of the opinion that the doctrine as elucidated in the Celebici case is too stringent in its requirements for prosecution, so that some offenders will potentially escape liability: Ilias Bantekas "The Contemporary Law of Superior Responsibility" 93 AJIL 142 - 143. 
the first international judgment since World War Two holding a superior liable for the crimes of his subordinates. ${ }^{65}$ After the ICTY formulated the doctrine in the Celebici case it has gone on to apply it in a number of other cases. ${ }^{66}$

Command responsibility has two aspects: responsibility for positive acts (for example, ordering, instigating, planning) and responsibility for culpable omissions, such as the failure to prevent or punish war crimes of subordinates. ${ }^{67}$ The latter omission-based (or "indirect") responsibility is based on the existence of a legal duty to act to prevent or punish crimes of subordinates. ${ }^{68}$ The trial court broke down the elements in command responsibility for failure to act as follows: ${ }^{69}$

(1) the existence of a superior-subordinate relationship;

(2) the superior knew or had reason to know that the criminal act was about to be or had been committed; and

(3) the superior failed to take the necessary and reasonable measures to prevent the criminal act or punish the perpetrator thereof.

The superior-subordinate relationship can be either de facto or de jure, and individuals can be criminally liable under the command responsibility doctrine when in non-military positions of superior authority. The relationship must be characterised by the superior having: ${ }^{70}$

65 Ching, above, 185.

66 Prosecutor $v$ Zlatko Aleksovski Judgment IT-95-14/1 (ICTY, 25 June 1999) [Aleksovski] $<$ http://www.un.org/icty/aleksovski/trialc/judgment/index.htm> (last accessed 3 July 2001); The Prosecutor v Thomir Blaskic Judgment IT-95-14 (ICTY, 3 March 2000) [Blaskic] <http://www.un.org/icty/blaskic/ trialc1/judgment/index.htm> (last accessed 12 August 2001); Prosecutor $v$ Radislav Kristic Judgment IT98-33 (ICTY, 2 August 2001) paras 647-651 [Kristic] <http://www.un.org/icty/krstic/TrialC1/ judgment/index.htm $>$ (last accessed 15 August 2001). In the last case as the court made a finding of criminal liability for Kristic under Article 7(1), direct command responsibility, it did not enter a conviction under Article 7(3) even though the tests were met for liability under that article, Kristic, above, para 651.

67 Prosecutor v Zejnil Delalic, Zdravko Mucic (aka "Pavo"), Hazim Delic and Esad Landžo (aka "Zenga") ["Celebici" Case Judgment] IT-96-21 (ICTY, 16 November 1998) para 417 [Celebici Case Trial Judgment] $<$ http://www.un.org/icty/celebici/trialc2/judgment/index.htm> (last accessed 3 July 2001) para $333-334$.

68 For example, First Protocol, Protocol Additional to the Geneva Conventions of 12 August 1949, and Relating to the Protection of Victims of International Armed Conflicts (Protocol I) (June 8 1977) 1125 UNTS 3 Article 85 [First Protocol], Art 86 and 87; Ilias Bantekas "The Contemporary Law of Superior Responsibility" 93 AJIL, 592 - 594.

69 Celebici Case Trial Judgment, above, para 346.

70 Prosecutor v Zejnil Delalic, Zdravko Mucic (aka "Pavo"), Hazim Delic and Esad Landžo (aka "Zenga") (" Celebici" Case) Judgment IT-96-21 (ICTY, 20 February 2001) paras 182-314 [Celebici Case Appeal Judgment] <http://www.un.org/icty/celebici/appeal/judgment/index.htm> (last accessed 3 July 2001) para 378 . 
... effective control over the persons committing the underlying violations of international humanitarian law, in the sense of having the material ability to prevent and punish the commission of these offences ... such authority can have a de jure or a de facto character.

This element was considered on appeal by the Appeals Chamber, which upheld the Trial Chamber's analysis of customary law, rejecting the prosecution's proposition that influence or powers of persuasion alone could found command responsibility. ${ }^{71}$ The Appeals Chamber held that the Trials Chamber had applied the correct test of "effective control". ${ }^{72}$ It was also noted that the $d e$ facto control element of the test allows for command responsibility to arise where the superiorsubordinate relationship is indirect in character, as opposed to a direct relationship in a military chain of command, and that the control itself could be of an indirect character. ${ }^{73}$

The mens rea element that the superior "knew or had reason to know that the criminal act was about to be or had been committed" can be satisfied by either actual knowledge or by possession of information sufficient to put the superior on notice of the risk of such offences having occurred or occurring. ${ }^{74}$ The prosecutor must establish actual knowledge through direct or circumstantial evidence. There is no presumption of knowledge merely because offences may have been widespread, numerous, publicly notorious, or committed over wide areas or over prolonged periods. ${ }^{75}$ However these factors may allow an inference to arise that he must have possessed that knowledge. ${ }^{76}$

71 Celebici Case Appeal Judgment, above, paras 248-268. For a criticism of this finding, see Ilias Bantekas "The Contemporary Law of Superior Responsibility" 93 AJIL 573, 574; Greg R Vetter "Command Responsibility of Non-Military Superiors in the International Criminal Court" (2000) 25 Yale J Int'l L 89, $95.581-582$.

72 Celebici Case Appeal Judgment, above, paras 266-267.

73 Celebici Case Appeal Judgment, above, paras 251-252.

74 Prosecutor v Zejnil Delalic, Zdravko Mucic (aka "Pavo"), Hazim Delic and Esad Landžo (aka "Zenga") ("Celebici" Case) Judgment IT-96-21 (ICTY, 16 November 1998) para 417 [Celebici Case Trial Judgment] $<$ http://www.un.org/icty/celebici/trialc2/judgment/index.htm> (last accessed 3 July 2001) para 383.

75 Bantekas argues that post World War II jurisprudence does establish a rebuttable presumption of actual knowledge where crimes were widespread and notorious, and that the ICTY's refusal to accept this presumption was "despite the weight of that precedent". Ilias Bantekas "The Contemporary Law of Superior Responsibility" 93 AJIL $588-590$.

76 Prosecutor v Zejnil Delalic, Zdravko Mucic (aka "Pavo"), Hazim Delic and Esad Landžo (aka "Zenga") ("Celebici" Case) Judgment IT-96-21 (ICTY, 16 November 1998) para 417 [Celebici Case Trial Judgment] $<$ http://www.un.org/icty/celebici/trialc2/judgment/index.htm> (last accessed 3 July 2001) paras 228 - 230. 
The second limb, "had reason to know" is consistent in meaning with the First Protocol Article 86 (2) reference to "... had information which should have enabled them to conclude ..."77 A commander therefore needs to be in possession of some information sufficient to put him on notice that crimes had been, or were going to be, committed. ${ }^{78}$ The types of information that can put a commander "on notice" vary, including oral and written reports, knowledge of levels of training and the character of his men; and for the information to be "in his possession" it is sufficient that it was available or provided to the superior, even if he did not acquaint himself with it. ${ }^{79}$ The Appeals Chamber rejected the prosecution's assertion that customary international law established a "duty to know" for military and civilian superiors. ${ }^{80}$ Such a duty would have the effect of making criminal liability under the doctrine of command responsibility a form of strict liability. As such it is necessary to establish particular information a superior had "in his possession" which was sufficient to put him on notice.

The third overall requirement is failure to take necessary and reasonable measures in accordance with their legal duty. ${ }^{81}$ A superior can only reasonably be expected to take such measures as are within their power to take, expressed by the trial court as "such measures that are within his material possibility". The ICTY Trial Chamber also notes that the "lack of formal legal competence to take the necessary measures to prevent or repress the crime in question does not necessarily preclude the criminal responsibility of the superior". ${ }^{82}$ The court noted that it is impossible to lay down strict guidelines on what might constitute necessary and reasonable measures outside of the context of the facts of a particular case. ${ }^{83}$

77 Protocol Additional to the Geneva Conventions of 12 August 1949, and Relating to the Protection of Victims of International Armed Conflicts (Protocol I) (June 8 1977) 1125 UNTS 3 Art 85 [First Protocol] Art 86(2).

78 Celebici Case Trial Judgment, para 387-393; Celebici Case Trial Judgment, above, paras 330-400; Prosecutor v Zejnil Delalic, Zdravko Mucic (aka "Pavo"), Hazim Delic and Esad Landžo (aka "Zenga") ("Celebici" Case) Judgment IT-96-21 (ICTY, 20 February 2001) paras 182 - 314 [Celebici Case Appeal Judgment] <http://www.un.org/icty/celebici/appeal/judgment/index.htm> (last accessed 3 July 2001) paras $231-236$.

79 Celebici Case Appeal Judgment, above, paras 238-239.

80 Celebici Case Appeal Judgment, above, paras 248-268.

81 "It has also been suggested that the concept of reasonableness is difficult to apply in this context since it requires a balancing of social costs and benefits when there are no accepted norms regarding the relative value of such things as war crimes prevention and military success." Andrew D Mitchell "Failure to Halt, Prevent or Punish: The Doctrine of Command Responsibility for War Crimes" 22 Sydney L Rev 381, 409.

82 Prosecutor v Zejnil Delalic, Zdravko Mucic (aka "Pavo"), Hazim Delic and Esad Landžo (aka "Zenga") ("Celebici" Case) Judgment IT-96-21 (ICTY, 16 November 1998) para 417 [Celebici Case Trial Judgment] $<\mathrm{http} / / /$ www.un.org/icty/celebici/trialc2/judgment/index.htm> (last accessed 3 July 2001) para 395.

83 Celebici Case Trial Judgment, above, paras 394-395. 
Given that there is an "effective control" test to found a superior-subordinate relationship, the nature of that control on the facts of a given case will affect what might constitute necessary and reasonable measures. Under some circumstances reporting the matter to "the competent authorities" may be sufficient to discharge this obligation. ${ }^{84}$ The factual framework of the superior-subordinate relationship, both de facto and de jure, the degree of control asserted, and the measures reasonably open to a superior in a given situation, to name just a few possible factors, will determine in a given fact situation what would have constituted necessary and reasonable measures.

\section{CIVILIAN SUPERIORS AND COMMAND RESPONSIBILITY}

Of particular concern in the scenario under consideration here is the applicability of the doctrine of command responsibility to civilian superiors. Several civilian superiors were tried following the Second World War. ${ }^{85}$ The ICTY's elucidation of customary international law includes the possibility of civilian superiors being found criminally liable under the doctrine of command responsibility. ${ }^{86}$ In 1998 the Prime Minister of Rwanda, Jean Kambanda pleaded guilty to various crimes before the ICTR, including counts under the ICTR's command responsibility provision. ${ }^{87}$ This was the first conviction of a Head of Government by an international tribunal. The Indictments of Radovan Karadzic ${ }^{88}$ and Slobodan Milosevic, ${ }^{89}$ the former Bosnian Serb Head of State for the Bosnian Serb Republic and the former Head of State of the FRY, include criminal liability on this basis. Milosevic is currently on trial at the ICTY, the first former Head of State to ever be tried by an international tribunal.

The elements required for a civilian leader under the doctrine of command responsibility are the same three discussed above for military commanders, with the exception of the definition of the

84 The Prosecutor v Thomir Blaskic Judgment IT-95-14 (ICTY, 3 March 2000) [Blaskic] <http://www.un.org/ icty/blaskic/trialc1/judgment/index.htm> (last accessed 12 August 2001) para 336.

85 For example, United States v Soemu Toyoda Official Transcript of Record of Trial [Toyoda]; Trial of Friederich Flick et al Vol VI TWC [Flick]; Government Commissioner v Roechling 14 TWC [Roechling].

86 Celebici Case Trial Judgment, above, para 355-363. The Trial Chamber considered the trial of some civilian leaders under the doctrine by the Tokyo Tribunal, as well as the Flick case, above, and the Roechling, case from Germany, above.

87 Prosecutor v Jean Kambanda ICTR-97-23-S (ICTR September 4, 1998) <http://www.un.org/ictr/english/ judgments/kambanda.html $>$ (last accessed 15 August 2001). Kambanda plead guilty to counts under Art 6(3) of the Statute of the International Criminal Tribunal for Rwanda, Art 3 [ICTR Statute] $<\mathrm{http}$ ://www.ictr.org/ENGLISH/basicdocs/statute.html > (last accessed 10 August 2001).

88 Indictment Prosecutor v Radovan Karadzic and Ratko Mladic (ICTY, July 1995) <http://www.un.org/ icty/indictment/english/kar-ii950724e.htm> (last accessed 12 July 2001).

89 Amended Indictment Prosecutor v Slobodan Milosevic, Milan Milutinovic, Nikola Sainovic, Dragoljub, Vlajko Stojilkovic IT-99-37-I (ICTY, 29 June 2001) <http://www.un.org/icty/indictment/english/milai010629e.htm> (last accessed 12 July 2001). 
superior-subordinate relationship. The ICTY's Aleksovski judgment ${ }^{90}$ considered that a civilian's position as a superior needed to be analogous to a military commanders, but that the civilian's "sanctioning power must be interpreted broadly". A civilian in most cases will not have the same extent of de jure powers a military commander has, for instance to arrest and charge an offender through the military discipline system. A civilian superior's ability de jure or de facto to impose sanctions is not essential to liability; the possibility of transmitting reports to the appropriate authorities may be enough to found liability. ${ }^{91}$ These qualifications may mitigate the restrictiveness of the Celebici conclusion that "... the doctrine of superior responsibility extends to civilian superiors only to the extent that they exercise a degree of control over their subordinates which is similar to that of military commanders." 92

This broader interpretation of the sanctioning power of a civilian superior, in order to satisfy the "effective control" test, impacts on the third requirement for failure to take necessary and reasonable measures. As noted above the interpretation of what necessary and reasonable measures are in a given case has to be determined within the context of the facts of the case. It follows from the effective control test, and the requirement to take measures within the superior's "material responsibility", that the nature of the control will be determinative of what constitutes necessary and reasonable measures. The civilian superior's lack of the coercive de jure authority vested in military commanders will necessarily dictate a different set of requirements to be discharged to meet their duty to take necessary and reasonable measures to prevent or punish.

The ICC Statute's provision for non-military command responsibility departs from the ICTY formulation. The ICC Statute structures its provisions on the doctrine of command responsibility in two parts, Article 28(a) covering a military commander or person effectively acting as a military commander, and Article 28(b) covering any other superior-subordinate relationship. The mens rea requirement for non-military indirect command responsibility in Article 28(b) is narrower than that determined in the Celebici case, requiring "the superior either knew, or consciously disregarded information which clearly indicated that the subordinates were committing or about to commit such crimes" $^{93}$ [emphasis added].

90 Prosecutor $v$ Zlatko Aleksovski Judgment IT-95-14/1 (ICTY, 25 June 1999) [Aleksovski] $<$ http://www.un.org/icty/aleksovski/trialc/judgment/index.htm> (last accessed 3 July 2001).

91 Aleksovski, above, para 78.

92 Prosecutor v Zejnil Delalic, Zdravko Mucic (aka "Pavo"), Hazim Delic and Esad Landžo (aka "Zenga") ("Celebici" Case) Judgment IT-96-21 (ICTY, 16 November 1998) para 417 [Celebici Case Trial Judgment] <http://www.un.org/icty/celebici/trialc2/judgment/index.htm> (last accessed 3 July 2001) para 378.

93 Under Art 126 of the Rome Statute of the International Criminal Court, 17 July 1998 (1998) 37 ILM 998 [ICC Statute] Art 28(b)(i). Contrasted with "Knew or had reason to know" in the Statute of the International Criminal Tribunal for the Former Yugoslavia, as amended 30 November 2000 by Resolution 1329 [ICTY Statute] <http://www.un.org/icty/basic/statut/stat2000_con.htm> (last accessed 16 August 2001). Art 7(3). 
In addition to the Celebici Ccse elements, the ICC Statute requires that in the case of nonmilitary superiors the crimes concerned are activities within the effective authority and control of the superior. ${ }^{94}$ The meaning of this extra element is unclear. ${ }^{95}$ Vetter notes that: ${ }^{96}$

... it is difficult to assess whether the ICC civilian standard is a departure from prior customary international law for civilian command responsibility for two reasons: (1) The holdings of the handful of civilian cases tried after World War II are subject to various interpretations, and (2) the source of a civilian superior's duty may be difficult to determine and may be less onerous than a military commander's duty.

The ICC formulation of the doctrine of command responsibility with respect to non-military superiors is arguably not international custom yet. The Celebici case is currently the most authoritative statement of the content of international custom, ${ }^{97}$ while only 80 States have ratified the ICC Statute. ${ }^{98}$ If all the 139 signatories ratify the ICC Statute then this may lead to some change in the customary position, though with some uncertainty as regards some of the persistent objectors. $^{99}$

The current international customary law doctrine of command responsibility, as regards civilian superiors, seems therefore to consist of:

94 ICC Statute, above, Art 28(b)(ii).

95 Greg R Vetter "Command Responsibility of Non-Military Superiors in the International Criminal Court" (2000) 25 Yale J Int'l L 89, 95, 119 - 120.

96 Vetter, above, 110.

97 Vetter, above, 111.

$98<$ http://untreaty.un.org/ENGLISH/bible/englishinternetbible/partI/chapterXVIII/treaty10.asp > (last accessed 18 September 2002).

99 For the persistent objector rule see Anglo-Norwegian Fisheries Case (1951) ICJ Rep 116. In this instance there were a small number of States that participated at the Rome Conference who did not sign the ICC Statute. The most significant was the United States of America. The statute was signed by the USA on 31 December 2000, however the Bush administration repudiated the treaty on 6 May 2002, with a communication to the United Nations Secretary General that "in connection with the Rome Statute of the International Criminal Court adopted on July 17, 1998, that the United States does not intend to become a party to the treaty. Accordingly, the United States has no legal obligations arising from its signature on December 31, 2000. The United States requests that its intention not to become a party, as expressed in this letter, be reflected in the depositary's status lists relating to this treaty." <http://untreaty.un.org/ ENGLISH/bible/englishinternetbible/partI/chapterXVIII/treaty10.asp\#N6> (last accessed 19 September 2002). The United States has since carried on a campaign to try to gain immunity for its soldiers from the jurisdiction of the ICC. BBC News Online "Washington Seeks Troop Immunity" 20 June 2002 $<$ http://news.bbc.co.uk/1/hi/world/americas/2056005.stm> (last accessed 19 September 2002). 
(1) The existence of a superior-subordinate relationship characterised by the superior having effective control over the subordinate. ${ }^{100}$ The control has to be analogous to that of military commander, but the civilian superior's sanctioning powers must be interpreted broadly. ${ }^{101}$

(2) The superior knew or had reason to know that the criminal act was about to be or had been committed. This is either actual knowledge, which can be inferred from the circumstances and evidence, ${ }^{102}$ or the commander must have been in possession of some information sufficient to put them on notice. ${ }^{103}$

(3) The superior failed to take the necessary and reasonable measures to prevent the criminal act or punish the perpetrator thereof. Such measures must be within the material possibility for the superior. ${ }^{104}$

With these qualifications in mind, are the three necessary elements made out for Clinton and Blair, with respect to the three incidents this paper is assuming are prima facie war crimes?

\section{THE DOCTRINE OF COMMAND RESPONSIBILITY AND BLAIR/CLINTON}

\section{A The Existence of a Superior - Subordinate Relationship}

Both Clinton and Blair were clearly in a position of direct superior authority vis-à-vis their own forces in the NATO coalition. As Head of State and Head of Government respectively, Clinton and Blair had sufficient authority, both de jure and de facto, to order measures to prevent offences or punish offenders within their own forces. Clinton, as President of the United States, is

100 Prosecutor v Zejnil Delalic, Zdravko Mucic (aka "Pavo"), Hazim Delic and Esad Landžo (aka "Zenga") ("Celebici" Case) Judgment IT-96-21 (ICTY, 16 November 1998) para 417 [Celebici Case Trial Judgment] $<$ http://www.un.org/icty/celebici/trialc2/judgment/index.htm> (last accessed 3 July 2001) para 378.

101 Prosecutor $v$ Zlatko Aleksovski Judgment IT-95-14/1 (ICTY, 25 June 1999) [Aleksovski] $<$ http://www.un.org/icty/aleksovski/trialc/judgment/index.htm> (last accessed 3 July 2001) para 78.

102 Prosecutor v Zejnil Delalic, Zdravko Mucic (aka "Pavo"), Hazim Delic and Esad Landžo (aka "Zenga") ("Celebici" Case) Judgment IT-96-21 (ICTY, 16 November 1998) para 417 [Celebici Case Trial Judgment] $<$ http://www.un.org/icty/celebici/trialc2/judgment/index.htm> (last accessed 3 July 2001); this principle is enshrined under Art 126 of the Rome Statute of the International Criminal Court, 17 July 1998 (1998) 37 ILM 998 [ICC Statute], Art 22, paras 228-230.

103 Celebici Case Trial Judgment, above, para 387-393; Celebici Case Trial Judgment, above, paras 330-400; Prosecutor v Zejnil Delalic, Zdravko Mucic (aka "Pavo"), Hazim Delic and Esad Landžo (aka "Zenga") ("Celebici" Case) Judgment IT-96-21 (ICTY, 20 February 2001) paras 182-314 [Celebici Case Appeal Judgment] <http://www.un.org/icty/celebici/appeal/judgment/index.htm> (last accessed 3 July 2001) paras 231-236.

104 Prosecutor v Zejnil Delalic, Zdravko Mucic (aka "Pavo"), Hazim Delic and Esad Landžo (aka "Zenga") ("Celebici" Case) Judgment IT-96-21 (ICTY, 16 November 1998) para 417 [Celebici Case Trial Judgment] $<$ http://www.un.org/icty/celebici/trialc2/judgment/index.htm> (last accessed 3 July 2001), para 395. 
constitutionally the Commander in Chief of the United States Armed Forces. Blair, as Prime Minister, is in a position of constitutional responsibility for the activities of the Executive Branch of Government. Both men would also meet the additional requirement from the ICC Statute for the activities concerned to be within their effective control, if that requirement was part of customary law.

\section{B Direct Liability}

Clinton and Blair could be held criminally liable if they ordered, instigated or planned any of the attacks that constituted a war crime. The only incident for which direct liability might arise is the attack on RTS. This direct liability would accrue if RTS were a civilian rather than a military object, turning the attack into a direct attack on the civilian population causing death in violation of Article 85(3)(a) of the First Protocol. The OTP concluded, on the evidence, that "insofar as the attack actually was aimed at disrupting the communications network, it was legally acceptable." ${ }^{105}$ The qualification in the finding was because NATO justified the attack on two grounds: that RTS was a command, control and communications centre; ${ }^{106}$ and on the grounds that it was used for a propaganda purpose. ${ }^{107}$ If NATO had based the attack purely on the latter ground the attack would probably have been illegal. ${ }^{108}$

The other criticisms of the attack, on the basis that it was a military target, revolve around allegations that it violated other principles of the laws and customs of war requiring proportionality ${ }^{109}$ and adequate warning. ${ }^{10}$ Clinton and Blair's direct involvement would most likely have been at the highest strategic level, the decision to attack. The timing and means of attack were operational and tactical decisions taken by their subordinates. Liability for violating these

105 Final Report to the Prosecutor by the Committee Established to Review the NATO Bombing Campaign Against the Federal Republic of Yugoslavia [OTP Final Report] para 75.

106 OTP Final Report, above, paras 72-73.

107 OTP Final Report, above, para 74.

108 The OTP are less direct, finding that "... its legality might well be questioned by some experts in the field of humanitarian law" OTP Final Report, above, para 90.

109 OTP Final Report, above, paras 48-52; Protocol Additional to the Geneva Conventions of 12 August 1949, and Relating to the Protection of Victims of International Armed Conflicts (Protocol I) (June 8 1977) 1125 UNTS 3 Article 85 [First Protocol] Art 57(2)(a)(iii).

110 Article 85 (3) "The following acts shall be regarded as grave breaches, when committed wilfully, in violation of the relevant provisions of this Protocol, and causing death ... (b) launching an indiscriminate attack affecting the civilian population or civilian objects in the knowledge that such attack will cause excessive loss of life, injury to civilians or damage to civilian objects ..." Protocol Additional to the Geneva Conventions of 12 August 1949, and Relating to the Protection of Victims of International Armed Conflicts (Protocol I) (June 8 1977) 1125 UNTS 3 Article 85 [First Protocol]. 
principles, arguably thereby causing the attack to become "indiscriminate", would be for indirect command responsibility.

For the other two attacks the alleged war crimes arose from the manner of attack, decided by the pilot working within their rules of engagement after the target had been selected. Neither Blair or Clinton were in a position to prevent these incidents, so any liability that might arise must do so through failure to punish the pilots if in fact a war crime was committed.

\section{Indirect Liability}

For each of the incidents both men could potentially be held liable through the doctrine of command responsibility if they failed to prevent or punish war crimes. As discussed above, once the superior-subordinate relationship has been established liability for the crimes of subordinates will be founded if it is established that:

(1) The superior knew or had reason to know that an offence was about to be committed, or had been committed; and

(2) The superior failed to take the necessary and reasonable measures to prevent such acts or to punish the perpetrators thereof.

\section{Mens rea - knew or had reason to know}

There is little difficulty in satisfying the mens rea requirement for both Clinton and Blair. The international media broadcast the facts of each of the attacks globally, while the campaign was still underway. ${ }^{111}$ NATO press briefings revealed the relevant facts of each of the incidents, in a matter of days. ${ }^{112}$ Given the sensitivity of any civilian casualties, and the potential to undermine support for NATO's actions, it is also likely that Clinton and Blair were receiving detailed briefings from their Defence Staff and NATO.

From the scrutiny and exposure by the international media, as well as statements made by Clinton and Blair, it would be possible to infer actual knowledge of the circumstances of the attacks giving rise to questions of their legality. Even if there were insufficient evidence to infer actual knowledge, the "had reason to know" test would be met. Both Clinton and Blair would have been in

111 For example, the attack on the refugee convoys at Djakovica: BBC News Online "NATO: We May Have Killed Refugees" (19 April 1999) <http://news.bbc.co.uk/hi/english/world/europe/ newsid_323000/323248.stm> (last accessed 21 August 2001).

112 For the Grdelica attack, Press Conference NATO HQ Brussels (13 April 1999) <http://www.nato.int/ kosovo/press/p990413a.htm> (last accessed 21 August 2001); for the Djakovica attack, Press Conference NATO HQ Brussels (15 April 1999) <http://www.nato.int/kosovo/press/p990415a.htm> (accessed 21 August 2001); for the attack on RTS, Press Conference NATO HQ Brussels (23 April 1999) $<$ http://www.nato.int/kosovo/press/p9904231.htm> (accessed 21 August 2001). 
possession of sufficient information to put them on notice that war crimes may have been committed. ${ }^{113}$

The discussion so far has focused on a failure to punish after the alleged offence was committed. If either man knew that such offences were likely to occur then they would be liable for failure to prevent them. Each of the alleged offences arises from tactical decisions taken by the pilots in the developing situation of the attack, or in the case of RTS an operational decision by NATO Command on the time and manner of the attack. It would be difficult to argue Clinton and Blair could have foreseen the situations and acted to prevent them. The only basis for such an argument would seem to be that the requirement to operate above 15,000 feet made lawful application of the laws of war "virtually impossible", and therefore there was a requirement to take action to prevent possible breaches, by reducing this limit. ${ }^{114}$ However the evidence does not seem to bear out this claim, as the statistics quoted above show. If operating above 15,000 feet made operating lawfully "virtually impossible" then one would expect far more than $0.9 \%$ of sorties to lead to civilian deaths. It seems therefore that, on the evidence, there is an insufficient basis to allege a failure by Clinton and Blair to prevent the commission of offences.

\section{Failure to take necessary and reasonable measures}

The last element required for omission-based command responsibility is the failure to take necessary and reasonable measures to either prevent the commission of crimes, or to punish the offenders if the crimes are committed. The discussion so far has concluded that both Clinton and Blair are superiors, both de jure and de facto, and that they knew or had reason to know that these three attacks may have constituted war crimes. Proceeding on the assumption that they are in fact prima facie war crimes, if the two leaders failed to take reasonable and necessary measures to punish the perpetrators they should be personally liable for the crimes.

NATO claimed to have initiated investigations into some of the incidents that are alleged to have comprised war crimes. However, the only incident that has given rise to any form of disciplinary proceedings is the bombing of the Chinese Embassy in Belgrade. The United States admitted responsibility, paid compensation to the families and the Chinese Government, a number of CIA officers were reprimanded and one was dismissed. No criminal proceedings have been undertaken. ${ }^{115}$

113 Prosecutor v Zejnil Delalic, Zdravko Mucic (aka "Pavo"), Hazim Delic and Esad Landžo (aka "Zenga") ("Celebici" Case) Judgment IT-96-21 (ICTY, 16 November 1998) para 417 [Celebici Case Trial Judgment] $<$ http://www.un.org/icty/celebici/trialc2/judgment/index.htm> (last accessed 3 July 2001) paras 387 - 393.

114 NATO/Federal Republic of Yugoslavia "'Collateral Damage' or Unlawful Killings? Violations of the Laws of War by NATO during Operation Allied Force" (EUR 70/018/2000) [Amnesty Report] $<$ http://web.amnesty.org/ai.nsf/Index/EUR700182000> (last accessed on 1 July 2001) s 4.

115 Final Report to the Prosecutor by the Committee Established to Review the NATO Bombing Campaign Against the Federal Republic of Yugoslavia, para 84. 
The main difficulty in this area is the lack of evidence of what, if any, measures NATO took following these incidents. Were internal investigations undertaken? Was the fact that such investigations were undertaken, and the results of those investigations, made known to Clinton and Blair? All of the participating NATO countries have Legal Departments in their armed forces and these may have carried out investigations of the lawfulness of questionable incidents. Most military organisations would carry out an investigation as a matter of course after an attack had gone wrong. For example, the United States pilots involved in a friendly fire attack in Afghanistan are being charged with manslaughter as the result of an investigation into the incident. ${ }^{116}$

If an investigation is conducted in good faith, and with due diligence, and it concludes that there was no breach of the laws or customs of war then that may negate the mens rea or the actus reus, or perhaps both, for indirect command responsibility. The commander would not know that a war crime was committed, as they would have a reasonable belief that in fact no offence had occurred, nor could it be argued they should have known because the initial reports that indicated an offence might have been committed had been contradicted by an investigation in good faith and with due diligence. The actus reus of "failure to take necessary and reasonable measures" could be negated as the initiation and completion of an investigation to determine if an offence had been committed, provided the investigation was conducted to a sufficient standard, should constitute reasonable measures. However, if a prosecution were brought it would be for a court or tribunal to assess whether the investigation and its findings were reasonable, and whether it was reasonable for the superior to rely on the findings. Otherwise superiors could escape criminal liability by relying on sham investigations, and turning their mind from considering the merits of the investigation.

The only material that has been found that might illuminate this point is contained in the ICC Statute $^{117}$ at Article 17. Under Article 17, the ICC is denied jurisdiction over an offence where a State with jurisdiction is currently investigating the offence, has investigated and decided not to prosecute, or has already tried the alleged offender for the offence, unless the actions of the State are being taken to effectively shield the person from responsibility. ${ }^{118}$ The legal test for determining whether an investigation has been sufficient to defeat the jurisdiction of the ICC is not entirely clear from the provisions, though Article 17(2)(c) refers to the need for the proceedings to be "conducted independently or impartially". An internal investigation by NATO, or by the member State whose aircraft was involved in an incident, may be challenged on the grounds of a lack of independence,

116 BBC News Online "Pilots Charged Over 'Friendly Fire' Deaths" (13 September 2002) $<$ http://news.bbc.co.uk/1/hi/world/americas/2256146.stm> (last accessed 19 September 2002). A cynic might attribute the decision to prosecute in this instance to the fact it was friendly troops, Canadians, that were killed. There has not been any prosecutions for instances where civilians have been killed by mistake.

117 Under Art 126 of the Rome Statute of the International Criminal Court, 17 July 1998 (1998) 37 ILM 998 [ICC Statute].

118 ICC Statute, above, Art 17 and Art 20(3). 
and would therefore need to be conducted in a fashion that will establish it was impartial, or by this test it could fail to defeat the ICC's jurisdiction. While not clearly on the point of "necessary and reasonable measures" for a commander, it does suggest that a sufficiently independent or impartial investigation should constitute necessary and reasonable measures.

Are internal investigations by NATO, or by one of the member States, sufficient to satisfy the "necessary and reasonable measures" requirement imposed by the doctrine of command responsibility, or to negate the mens rea of Clinton and Blair? Without access to the investigation terms of reference and findings there is no way to know if these investigations were conducted in a sufficiently independent or impartial manner that would render them such. However, the debate over the lawfulness of these incidents illustrates that they are not clear violations of the laws and customs of war. It could well be open for a properly conducted investigation to find that no violation occurred, and it is therefore possible that properly conducted investigations were conducted that could negate the mens rea or actus reus for indirect command responsibility.

\section{Liability for Omission to Act and the RTS Strike: Command Responsibility and Multinational Coalitions: a Diffusion of Responsibility?}

Operation Allied Force was an example of a multinational coalition force in action. Western armies seem to accept that the formation of coalitions will be the normal way of reacting to and meeting threats in the future. ${ }^{119}$ This has been seen in recent military operations under the United Nations aegis, ${ }^{120}$ and regionally based operations. ${ }^{121}$ The command and control of multinational coalitions is a complex web of military and political constraints, and the force commander will in many cases not have full and unrestricted command of all the various national elements in the coalition. Individual national contingents will often relay orders back to their nations for military and political decision-makers to consider whether they are compatible with national objectives and restrictions.

What are the implications of coalition operations for the doctrine of command responsibility? Amnesty International claims that: ${ }^{122}$

119 For example, Major General Robert H Scales writes: "For the foreseeable future the United States will remain reluctant to intervene unilaterally in most crises; as a consequence, the need for coalition partners will shape American strategy." Robert H Scales "Future Warfare Anthology" (US Army War College, Carlisle Barracks, Pennsylvania, April 1999).

120 The Gulf War 1990, Somalia (UNOSOM), Bosnia (UNPROFOR), East Timor (UNTAET).

121 The intervention by ECOMOG in Sierra Leone and Liberia, NATO actions in Bosnia (IFOR then SFOR) and Kosovo (Operation Just Cause and then KFOR).

122 NATO/Federal Republic of Yugoslavia "'Collateral Damage' or Unlawful Killings? Violations of the Laws of War by NATO during Operation Allied Force" (EUR 70/018/2000) [Amnesty Report] $<$ http://web.amnesty.org/ai.nsf/Index/EUR700182000> (last accessed on 1 July 2001) s 2.4. 
Operation Allied Force was fought by a coalition of NATO member states in the name of the alliance as a whole ... at no point during the air campaign did any alliance member publicly repudiate any of the attacks carried out by NATO forces. Therefore each NATO member may incur responsibility for the military actions carried out under the NATO aegis.

This proposition has two aspects, State responsibility for each and every war crime committed by NATO, and individual criminal responsibility through the doctrine of command responsibility. The first aspect is not within the scope of this discussion. In terms of individual criminal responsibility, is this Amnesty International proposition supportable? As noted above the idea that command responsibility is a strict liability offence must be rejected, so there cannot be individual liability predicated merely on the fact a military or civilian superior is a member of NATO, and failed to repudiate attacks that were of questionable legality. Any liability would have to be predicated on satisfaction of the legal tests discussed above for the doctrine of command responsibility. What the Amnesty proposition does highlight is the potential difficulties that complex multi-national coalitions with complex, and blurred, command and control relationships pose to the doctrine of command responsibility.

The strike on RTS provides an example of this. Amnesty alleges that there was disagreement among the NATO partners as to the legality of the strike on RTS. As a result one nation, reportedly the United States, went ahead with the attack despite the objections of the other NATO partners. ${ }^{123}$ If that strike did, in the event, constitute a war crime could criminal liability be attributed to the superiors of the other, objecting, NATO partners?

The difficulty for analysis is in determining whether the military and relevant political superiors had the necessary control over the United States to prevent the bombing. Given that the relationship is a complex, and to some extent indeterminate mix, of military and political influence a court might have some difficulty in determining if there was the requisite control. Also the degree of control will vary with each nation; so Spain's influence with the United States may be less than the United Kingdom's. The national element that conducted the strike may have done so without the command approval of NATO command. What then is the position of the various commanders in the NATO hierarchy? It is important to note that the test of effective control, and the fact that such control can be indirect and de facto, means that more than one superior may be held responsible for a crime committed by a subordinate. ${ }^{124}$ So where the relevant tests set out for the doctrine of command responsibility are met liability could extend across a coalition, and not just directly up the chain of command.

123 Amnesty Report, above, s 5.3, citing press reports.

124 The Prosecutor $v$ Thomir Blaskic Judgment IT-95-14 (ICTY, 3 March 2000) [Blaskic] $<$ http://www.un.org/icty/blaskic/trialc1/judgment/index.htm> (last accessed 12 August 2001) para 303. 
What constitute necessary and reasonable measures in the context of a complex coalition? Assume that NATO's humanitarian intervention was lawful. What constitute necessary and reasonable measures given the political necessity to hold together a complex multinational coalition to achieve a lawful objective? This is a difficult question. It is not within the scope of this paper to address these complex issues. Suffice to say that they are real and important issues, given the shift that most developed nations are making to the concept of the multinational coalition as the standard force structure to confront the security challenges of the twenty-first century.

These difficulties do present a major challenge for any prosecution of Clinton and Blair. The identity of the aircraft and pilots involved in the incidents is not certain. If they were United States aircraft, does Blair escape the possibility of liability? Conversely, if the aircraft were from the United Kingdom does Clinton escape liability? Or do both men escape liability because their national forces were detached from national command and operating under NATO leadership? Problems of proof were identified as one of the factors in the OTP decision that no further investigation was warranted. ${ }^{125}$ The only incident where this may not impede prosecution is direct command responsibility for ordering the attack on RTS, if it was a civilian object and not a military target, as liability is incurred for giving the orders and the identity of the attacking aircraft is irrelevant.

\section{SOVEREIGN IMMUNITY, WAR CRIMES AND CRIMES AGAINST HUMANITY}

Assuming that criminal liability could be founded through the doctrine of command responsibility, what protection do Clinton and Blair receive from their positions as a former Head of State and current Head of Government a under international law? International law has traditionally granted immunities to the Head of State and to diplomats, though the extent of this immunity has been narrowed over time. In conflict with this doctrine of sovereign immunity is the principle of individual criminal responsibility for serious international crimes.

\section{A The International Law Principles of Sovereign Immunity and Individual Criminal Responsibility}

1 The principle of sovereign immunity

Traditional head of state immunity, as a norm of customary international law, was an aspect of sovereign immunity. This is a principle that acts to prevent the courts of one State sitting in

125 "In all cases, either the law is not sufficiently clear or investigations are unlikely to result in the acquisition of sufficient evidence to substantiate charges against high level accused or against lower accused for particularly heinous offences." Final Report to the Prosecutor by the Committee Established to Review the NATO Bombing Campaign Against the Federal Republic of Yugoslavia, para 90. 
judgment on the acts of another State. ${ }^{126}$ This principle has its roots in the equality of States at the international level. ${ }^{127}$ The extension of sovereign immunity to the Head of State was based in the idea of the Head of State, the sovereign, as the personification of the State. ${ }^{128}$ In their domestic law, States base head of state immunity on such grounds as sovereign immunity, diplomatic immunity and the Act of State doctrine. ${ }^{129}$

The initial restrictions on the doctrine of head of state immunity came within the field of civil law, drawing a distinction between private acts and official acts, particularly in the case of commercial transactions, ${ }^{130}$ though the recognition of these exceptions is not universal. ${ }^{131}$ The immunity of Heads of State belongs to the State, and not the person, so that the State may waive its immunity for a Head of State or diplomat. ${ }^{132}$ The analysis of sovereign immunity in the Pinochet ${ }^{133}$ decision drew a distinction between the immunity enjoyed by a sitting Head of State and that

126 Gilbert Sison "Recent Development: A King No More: The Impact of the Pinochet Decision on the Doctrine of Head of State Immunity" (2000) 78 Wash ULQ 1583, 1584-1587.

127 This principle is reflected in The International Criminal Tribunal for the Former Yugoslavia $<$ http://www.un.org/icty/index.html > (last accessed 20 July 2001) [ICTY]; International Criminal Tribunal for Rwanda <http://www.ictr.org/> (last accessed 10 June 2001) [ICTR]. The ICTY was created pursuant to the Security Council Resolution 827 of 25 May $1993<\mathrm{http}$ //www.un.org/icty/basic/statut/S-RES827 93.htm $>$ (last accessed 12 August 2001); the ICTR was created by the Security Council Resolution 955 of $\overline{8}$ November $1994<\mathrm{http}$ //www.ictr.org/ENGLISH/Resolutions/955e.htm> (last accessed 12 August 2001). Both tribunals were established under Chapter VII of the Charter of the United Nations [UN Charter] $<$ http://www.unhcr.ch/html/menu3/b/ch-cont.htm> (last accessed 12 August 2001) at Art 2(1).

128 Joint (separate) opinion of Judges Higgins, Kooijmans and Buergenthal in the Case Concerning the Arrest Warrant of 11 April 2000 (Democratic Republic of the Congo v Belgium) (14 February 2002) ICJ para 80 [DRC v Belgium Joint Separate Opinion] <http://www.icj-cij.org/icjwww/idocket/iCOBE/icobejudgment/ icobe_ijudgment_20020214_higgins-kooijmans-buergenthal.PDF> (last accessed 20 September 2002). The facts of the case are discussed in the majority decision, Case Concerning the Arrest Warrant of 11 April 2000 (Democratic Republic of the Congo v Belgium) (14 February 2002) ICJ [DRC v Belgium] $<$ http://www.icj-cij.org/icjwww/idocket/iCOBE/icobejudgment/icobe_ijudgment_20020214.PDF> (last accessed 20 September 2002).

129 Sison, above, $1584-1585$.

130 Governor of Pitcairn and Associated Islands v Sutton [1995] 1 NZLR 426, 428 (CA) Cooke P.

131 For example, Russia adheres to a view of absolute immunity, Gilbert Sison "Recent Development: A King No More: The Impact of the Pinochet Decision on the Doctrine of Head of State Immunity" (2000) 78 Wash ULQ 1587.

132 Ruth Wedgwood " $40^{\text {th }}$ Anniversary Perspective: International Criminal Law and Augusto Pinochet" (2000) 40 Va J Int'1 L 829, 838.

133 Draft Code of Crimes against the Peace and Security of Mankind 1996 Art 18 [ILC Draft Code] $<$ http://www.un.org/law/ilc/texts/dcodefra.htm> (last accessed 1 April 2001). The Draft Code was provisionally adopted in 1988: Regina $v$ Bartle and the Commissioner of Police for the Metropolis and Others, Ex Parte Pinochet; Regina v Evans and Another and the Commissioner of Police for the Metropolis and Others, Ex Parte Pinochet [1999] UKHL 17, Lord Goff, paras 83 - 84 [Pinochet]. 
enjoyed by a former Head of State. A current Head of State's immunity attaches to their person (ratione personae) and is an absolute procedural immunity, while a former Head of State's immunity attaches only to official acts performed in their official capacity (ratione materiae). ${ }^{134}$ This analysis seems to be supported by the recent International Court of Justice (ICJ) Case Concerning the Arrest Warrant of 11 April 2000 (Democratic Republic of the Congo v Belgium) ${ }^{135}$ which dealt with the immunities of a Foreign Minister, but did so by effectively assimilating their position to that of Head of State. ${ }^{136}$ The ICJ concluded that a Foreign Minister had an absolute immunity to prosecution by domestic courts whilst in office, ${ }^{137}$ and once removed from office retained a substantive immunity for any official acts performed whilst in office. ${ }^{138}$ This is effectively the ratione personae/ratione materiae distinction. The other significance of this case for the purposes of the examination of Tony Blair's liability is that as a Head of Government he will enjoy immunities that are at least as extensive as a Foreign Minister's.

\section{Sison, above, 1588}

135 Joint (separate) opinion of Judges Higgins, Kooijmans and Buergenthal in the Case Concerning the Arrest Warrant of 11 April 2000 (Democratic Republic of the Congo v Belgium) (14 February 2002) ICJ para 80 [DRC v Belgium Joint Separate Opinion] <http://www.icj-cij.org/icjwww/idocket/iCOBE/icobejudgment/ icobe_ijudgment_20020214_higgins-kooijmans-buergenthal.PDF $>$ (last accessed 20 September 2002). The facts of the case are discussed in the majority decision, Case Concerning the Arrest Warrant of 11 April 2000 (Democratic Republic of the Congo v Belgium) (14 February 2002) ICJ [DRC $v$ Belgium] $<$ http://www.icj-cij.org/icjwww/idocket/iCOBE/icobejudgment/icobe_ijudgment_20020214.PDF> (last accessed 20 September 2002). Belgium issued an international arrest warrant against the Foreign Minister of the Democratic Republic of the Congo (DRC) under a domestic law giving Belgian courts universal jurisdiction over breaches of international humanitarian law, DRC v Belgium, above, para 15. The charges against the Minister, Mr Ndombasi, included grave breaches of the Geneva Conventions and Protocols and crimes against humanity, DRC v Belgium, above, para 13. The DRC took the case before the ICJ seeking a declaration that Belgium was acting in violation of international law on the basis of "...the rule of customary international law concerning the absolute inviolability and immunity from criminal process of incumbent foreign ministers", and an order that Belgium recall and cancel the unlawful warrant. This was a majority decision by 13 votes to three, Judges Oda, Al-Kwasawneh and Judge ad hoc Van den Wyngaert dissenting. However, a further three judges in a separate opinion found faults with some of the reasoning of the majority, in particular the failure to address the issue of jurisdiction prior to that of immunity, suggesting that "In agreeing to pronounce upon the question of immunity without addressing the question of a jurisdiction from which there could be immunity, the Court has allowed itself to be manoeuvred into answering a hypothetical question." DRC v Belgium Joint Separate Opinion, above, para 17.

136 The majority has arguably assimilated the immunities of a Foreign Minister to that of Head of State as the immunities they identify tally exactly with those of a Head of State, immunity ratione personae while in office and ratione materiae after they have left office.

137 The possibility of prosecution by an international tribunal or Court is left open, Case Concerning the Arrest Warrant of 11 April 2000 (Democratic Republic of the Congo v Belgium) (14 February 2002) ICJ [DRC v Belgium] <http://www.icj-cij.org/icjwww/idocket/iCOBE/icobejudgment/icobe_ijudgment_20020214.PDF> (last accessed 20 September 2002) para 61.

138 DRC v Belgium Joint (separate) opinion, above. For the facts see DRC v Belgium, above, see paras 54-55 and 61 . 


\section{The principle of individual criminal responsibility and irrelevance of official position}

Since World War Two, with respect to serious international crimes, international custom has restricted the application of this doctrine of sovereign immunity. ${ }^{139}$ The Nürnberg Tribunal in Article 7 of its charter excluded any immunity based on official status, including that of Head of State or Head of Government. ${ }^{140}$ This provision was included in the Tokyo Charter at Article 6, the ICTY Statute at Article 7(2), ${ }^{141}$ the ICTR Statute at Article 6, ${ }^{142}$ the ICC Statute at Article 27, ${ }^{143}$ and was recognised by the ILC in the Nürnberg principles at Principle III, ${ }^{144}$ and the ILC Draft Code at Article 7. ${ }^{145}$

This principle of individual criminal responsibility denies substantive immunity to international criminals, though their sovereign immunity will provide procedural immunity before domestic courts $^{146}$ and even perhaps international tribunals. ${ }^{147}$ The reasoning of the Pinochet decision ${ }^{148}$ is to

139 Though the possibility of its individual criminal liability overcoming sovereign immunity was mooted after the First World War, see the Commission on Responsibility Report, above, 122-123.

140 Article 6 of the Charter provides that "Leaders, organisers, instigators and accomplices participating in the formulation or execution of a common plan or conspiracy to commit any of the foregoing crimes are responsible for all acts performed by any persons in execution of such plan." Agreement for the Prosecution and Punishment of the Major War Criminals of the European Axis, and Charter of the International Military Tribunal. London, 8 August 1945 [Nürnberg Charter] <http://www.icrc.org/ihl.nsf/ 385ec082b509e76c41256739003e636d/59e5a3f396d98cc3c125641e00405ea7?OpenDocument> (last accessed 9 August 2001). This incorporates the first limb of command responsibility as discussed below, liability for positive acts, but makes no mention of liability for omission to prevent or punish, or indirect liability: Art 7.

141 Statute of the International Criminal Tribunal for the Former Yugoslavia, as amended 30 November 2000 by Resolution 1329 [ICTY Statute] <http://www.un.org/icty/basic/statut/stat2000_con.htm> (last accessed 16 August 2001) Art 7(2).

142 Statute of the International Criminal Tribunal for Rwanda, Article 3 [ICTR Statute] <http://www.ictr.org/ ENGLISH/basicdocs/statute.html> (last accessed 10 August 2001) Art 6.

143 Under Art 126 of the Rome Statute of the International Criminal Court, 17 July 1998 (1998) 37 ILM 998 [ICC Statute] Art 27.

144 Principles of International Law Recognised in the Charter of the Nürnberg Tribunal and in the Judgment of the Tribunal, Yearbook of the International Law Commission, 1950, Vol III. $<$ http://www.un.org/law/ilc/texts/nurnfra.htm> (last accessed 4 July 2001)

145 Draft Code of Crimes against the Peace and Security of Mankind 1996 Art 18 [ILC Draft Code] $<$ http://www.un.org/law/ilc/texts/dcodefra.htm> (last accessed 1 April 2001).

146 The facts of the case are discussed in the majority decision, Case Concerning the Arrest Warrant of 11 April 2000 (Democratic Republic of the Congo v Belgium) (14 February 2002) ICJ [DRC $v$ Belgium] $<$ http://www.icj-cij.org/icjwww/idocket/iCOBE/icobejudgment/icobe_ijudgment_20020214.PDF> (last accessed 20 September 2002).

147 "Princeton Principles" on Universal Jurisdiction (2001, Princeton University) [Princeton Principles] 48-51 $<$ http://www.princeton.edu/ lapa/unive_jur.pdf $>$ (last accessed 29 August 2001). DRC v Belgium, above. 
deny that international crimes can be "official acts" carried out in the public capacity of the individual, and therefore protected by immunity ratione materiae. ${ }^{149}$ This is an important point as many of the most serious international crimes, such as genocide, crimes against humanity and torture, tend to be carried out by States as official policy, with State officials deciding on and implementing the policy. If immunity ratione materiae protects all official acts, and the acts that constitute these serious crimes are characterised as official acts, then sovereign immunity will effectively result in impunity for the most serious offenders. A Head of State who planned and ordered the acts would escape liability while the individual who follows their orders unshielded by that immunity can be prosecuted. This difficulty is recognised in some of the separate opinions in the $D R C v$ Belgium case, but is not an issue addressed by the majority. ${ }^{150}$

How far do these various instruments reflect the state of international customary law? The ICTY considers its Statute to be reflective of customary international law, and it is interpreted to be consistent with custom as at the time of the offences. ${ }^{151}$ The quality of the jurisprudence of the Tribunal lends some support to its claims. The ILC also considers that this principle of individual

Para 61 leaves open the possibility of the prosecution of a Foreign Minister by an international Tribunal or Court even while in office. For a Foreign Minister therefore the ratione personae attached to their position is opposable only to domestic courts. This does not settle the question of the ratione personae of a Head of State with respect to international tribunals, which was not at issue before the ICJ.

148 Draft Code of Crimes against the Peace and Security of Mankind 1996 Art 18 [ILC Draft Code] $<$ http://www.un.org/law/ilc/texts/dcodefra.htm> (last accessed 1 April 2001). The Draft Code was provisionally adopted in 1988: Regina $v$ Bartle and the Commissioner of Police for the Metropolis and Others, Ex Parte Pinochet; Regina $v$ Evans and Another and the Commissioner of Police for the Metropolis and Others, Ex Parte Pinochet [1999] UKHL 17, Lord Goff, paras 83 - 84 [Pinochet].

149 Andrea Bianchi "Immunity versus Human Rights: The Pinochet Case" EJIL On-line Section 2D $<$ http://www.ejil.org/journal/Vol10/No2/art1-02.html\#TopOfPage> (last accessed 19 August 2001).

150 Case Concerning the Arrest Warrant of 11 April 2000 (Democratic Republic of the Congo v Belgium) (14 February 2002) ICJ [DRC v Belgium] <http:/www.icj-cij.org/icjwww/idocket/iCOBE/icobejudgment/ icobe_ijudgment_20020214.PDF> (last accessed 20 September 2002), para 85; Dissenting Opinion of Judge Al-Khasawneh in DRC v Belgium, para 6 [DRC v Belgium Al-Khasawneh Dissent]<http://www.icjcij.org/icjwww/idocket/iCOBE/icobejudgment/icobe_ijudgment_20020214_al-khasawneh.PDF> (last accessed 22 September 2002); Dissenting Opinion of Judge Van Den Wyngaert in DRC v Belgium, para 36

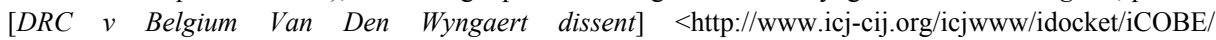
icobejudgment/icobe_ijudgment_20020214_vdwyngaert.PDF> (last accessed 22 September 2002).

151 The ICTY has jurisdiction over offences committed within the territories of the Former Yugoslavia from 1 January 1991, ICTY Statute, above, Art 1. The ICTY's consideration of international law is grounded in this time period, and subsequent developments, such as the emergence of the ICC, may effect changes on the content of customary international law in the future. See below para 31. 
accountability even for Heads of State or Government is reflective of custom, as developed after World War Two and reflected in the various international instruments cited above. ${ }^{152}$

State practice in many cases may seem to belie this principle. Many States harbour former Heads of State from justice: Idi Amin in Saudi Arabia, Mengistu Haile Mariam in Zimbabwe, Jean Claude (Baby Doc) Duvalier in France, to name a few. ${ }^{153}$ However, the fact that some States deviate from an otherwise accepted norm does not prevent that norm hardening into a rule of customary international law. ${ }^{154}$ On the other side of the ledger, the former president of FRY, Milosevic, is currently being tried before the ICTY. ${ }^{155}$ As noted above the Prime Minister of Rwanda has already been convicted by the ICTR. The State practice evidenced by the Tribunals following the World War Two, the attitude of States to the formation of the ICTY and ICTR under Chapter VII of the Charter, ${ }^{156}$ and the wide consensus on the Statute of the ICC, ${ }^{157}$ all constitute evidence of opinio juris and State practice.

152 Report of the International Law Commission on the work of its forty-eighth session (6 May-26 July 1996) General Assembly Official Records - Fifty-first Session Supplement No. 10 (A/51/10), Chapter II, commentary on Art 7, para 6 [ILC Report 1996] <http://www.un.org/law/ilc/reports/1996/96repfra.htm> (last accessed 15 August 2001).

153 Mary Margaret Penrose "It's Good to be the King!: Prosecuting Heads of State and Former Heads of State Under International Law" 39 Colum J Transnat'l L 193, 196.

154 State practice must be consistent, not rigidly uniform, Military and Paramilitary Activities in and against Nicaragua (Merits) [1986] ICJ Reports 14, 99-100 [Nicaragua Case].

155 CNN "Lawyer Says Milosevic to Accept Help" (4 July 2001) http://www.cnn.com/2001/WORLD/europe/ 07/03/milosevic.court/index.html (last accessed 12 August 2001); Ruth Wedgewood "Former Yugoslav President Slobodan Milosevic To Be Tried in The Hague for Crimes Against Humanity and War Crimes Allegedly Committed in Kosovo" ASIL Insights (July 2001) <http://www.asil.org/insights/insigh76.htm> (last accessed 20 July 2001).

156 The Security Resolution itself is not evidence of State practice, but the attitudes of States to the resolution, and to the formation and conduct of the Tribunals is. Significantly for the ICTY, the States most concerned with the institution have recently cooperated with the ICTY in extraditing some of their indicted nationals. For Croatia, see BBC News Online "Croatia's War Crimes Legacy" (16 July 2001) < http://news.bbc.co.uk/ hi/english/world/europe/newsid 1441000/1441771.stm> (last accessed 12 August 2001); for Serbia, see BBC News Online "Serbs Hand Over War Crimes Suspect" (23 March 2001) <http://news.bbc.co.uk/ hi/english/world/europe/newsid_1238000/1238793.stm> (last accessed 12 August 2001), and also the transfer of Milosevic to the ICTY, "Milosevic to Accept Help", above, for Bosnia, see BBC News Online "More Bosnia Arrests Urged" (3 August 2001) <http://news.bbc.co.uk/hi/english/world/europe/ newsid_1471000/1471954.stm> (last accessed 12 August 2001).

157139 signatories and 80 ratifications to the ICC Statute, <http://untreaty.un.org/ENGLISH/bible/ englishinternetbible/partI/chapterXVIII/treaty10.asp> (last accessed 18 September 2002), as at 18 September 2002. To put this in perspective there are currently 191 member States of the United Nations. 
The minority of the ICJ in DRC v Belgium, and three judges in the majority, accept that the principle of individual criminal responsibility is a part of customary law, ${ }^{158}$ while the majority note only that "immunity from criminal jurisdiction and individual criminal responsibility are quite separate concepts" and do not examine the customary status of the principle of individual criminal responsibility. ${ }^{159}$ What the ICJ denies is that a domestic court can have jurisdiction in the face of procedural immunity, in the case of a Foreign Minister. The principle of individual criminal responsibility is accepted, it is the application of this principle in the face of sovereign immunity that is the point of dispute.

\section{B The Conflict between the Principle of Sovereign Immunity and Individual Criminal Responsibility}

This conflict between the principle of individual criminal responsibility for international crimes, regardless of any official capacity, and the doctrine of sovereign immunity is still not fully resolved. The ICJ case, if it represents the current international law position, ${ }^{160}$ seems to have resolved this conflict as regards domestic courts. Domestic courts have no basis in international law to take jurisdiction in the face of ratione personae immunity, unless the State waives that immunity. Domestic courts could take jurisdiction where immunity is only ratione materiae, but only in regard to non-official acts, any acts characterised as official retain the sovereign immunity. ${ }^{161}$ As discussed above, it is not clear that the Pinochet reasoning that would exclude serious international crimes from classification as an official act is a part of customary international law. However, it is suggested that this reasoning is implicit in the customary principle of individual criminal

158 Case Concerning the Arrest Warrant of 11 April 2000 (Democratic Republic of the Congo v Belgium) (14 February 2002) ICJ [DRC v Belgium] <http://www.icj-cij.org/icjwww/idocket/iCOBE/icobejudgment/ icobe_ijudgment_20020214.PDF> (last accessed 20 September 2002), para 7 where Judge Al-Khasawneh states this principle is of a jus cogens character and consequently should defeat the non-jus cogens principle of immunity; DRC v Belgium Separate Joint Opinion, Joint (separate) opinion of Judges Higgins, Kooijmans and Buergenthal in the Case Concerning the Arrest Warrant of 11 April 2000 (Democratic Republic of the Congo v Belgium) (14 February 2002) ICJ para 80 [DRC v Belgium Joint Separate Opinion] $<$ http://www.icj-cij.org/icjwww/idocket/iCOBE/icobejudgment/icobe_ijudgment_20020214_higginskooijmans-buergenthal.PDF $>$ (last accessed 20 September 2002), para 85; Dissenting Opinion of Judge A1Khasawneh in DRC $v$ Belgium, para $6[$ DRC $v$ Belgium Al-Khasawneh Dissent $]<\mathrm{http} / /$ www.icjcij.org/icjwww/idocket/iCOBE/icobejudgment/icobe_ijudgment_20020214_al-khasawneh.PDF> (last accessed 22 September 2002); Dissenting Opinion of Judge Van Den Wyngaert in DRC v Belgium, para 36

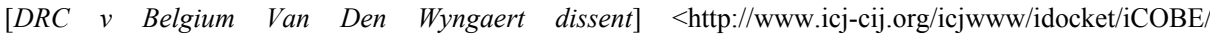
icobejudgment/icobe_ijudgment_20020214_vdwyngaert.PDF> (last accessed 22 September 2002) para 74; DRC v Belgium Van den Wyngaert dissent, paras $27-28$.

159 DRC v Belgium, above, para 60.

160 The reasoning of the court is very cursory, and there is some force in the criticisms of the dissenting judgments, and the separate joint opinion.

161 DRC v Belgium, above, para 61. 
responsibility regardless of official capacity, as otherwise that principle is deprived of its meaning and force.

The ICJ does indicate four exceptions where immunity would not lead to impunity: ${ }^{162}$

(1) They can be tried domestically within their own State, under domestic law;

(2) They can be tried by a domestic court of another State where the State they represent waives the immunity;

(3) After they leave office where the domestic court of another State has jurisdiction under international law the court can try them for acts committed prior to, or after, their term of office, or for acts committed during their term of office committed in a private capacity; and

(4) Where an international tribunal has jurisdiction an incumbent or former Minister of Foreign Affairs can be tried. Specific mention is made of the ICTR, ICTY and the ICC.

A State where the current government, or senior members of it, have allegedly been engaged in serious international crimes is unlikely to either prosecute these individuals itself, while they are still in power, and nor is the government likely to waive their immunity so they can be tried by the domestic court of another State. The possibility of prosecution after they have left office may encourage such governments to try to maintain themselves in power by further repression, torture, crimes against humanity, and so on in order to avoid justice. Even if they are forced from office the classification of what is an "official act" and protected by the continuing immunity ratione materiae is not clear.

The final option, that of international justice, is fraught with difficulties that are the result of the Court's reasoning. The Court concludes that not only is there no customary international law that allows domestic courts to overcome sovereign immunity, ${ }^{163}$ but that "... although various international conventions on the prevention and punishment of certain serious crimes impose on States obligations of prosecution or extradition, thereby requiring them to extend their criminal jurisdiction, such extension of jurisdiction in no way affects immunities under customary international law, including those of Ministers of Foreign Affairs. These remain opposable before the courts of a foreign State, even where those courts exercise such a jurisdiction under these conventions." 164

162 DRC v Belgium, above, para 61.

163 DRC v Belgium, above, para 58.

164 DRC v Belgium, above, para 59. 
In many States, an individual may only be arrested and extradited to another court, including an international court, by a domestic judicial process. ${ }^{165}$ Therefore, in order for an international court, which has no means to effect arrests itself, to actually gain possession of an offender in order to try them that offender must first be arrested by a State, and then extradited. Yet according to the reasoning of the ICJ the domestic courts cannot gain jurisdiction in the face of the offender's sovereign immunity even where domestic courts exercise a jurisdiction under an international convention. So even though New Zealand has jurisdiction under the International Crimes and International Criminal Court Act 2000, which implements New Zealand's treaty obligations under the ICC Statute, to arrest and surrender alleged offenders to the ICC, if New Zealand was to assert jurisdiction in order to surrender an individual with sovereign immunity then New Zealand would be in breach of international law. ${ }^{166}$ The Statute of the ICC is an international convention, and therefore domestic jurisdiction founded under it is not opposable to sovereign immunity under the ICJ's reasoning. This last option to avoid impunity is therefore rendered ineffective by the ICJ's own reasoning. A further limitation on this last of the ICJ's options for avoiding impunity is the lack of competent international tribunals to try offenders, with the ICTY and ICTR limited jurisdictionally by time and geography, ${ }^{167}$ and the ICC limited by time and by limitations on its jurisdiction over States who are not parties to its statute. ${ }^{168}$

165 Even though the final decision to surrender a person to the ICC under the International Crimes and International Criminal Court Act 2000 rests with the Minister of Justice, ss 47-54, in this process New Zealand is subjecting the individual to its domestic jurisdiction. On arrest the individual must be taken before the District Court, ss 39-41, and the Court must make a determination on the individuals eligibility for surrender, s 43: The right to challenge the arrest via habeus corpus is not excluded, and there are rights of appeal to the courts against a surrender order, s 67.

166 The exception to this may be where a State is acting in accordance with a resolution of the UNSC made under Chapter VII of the Charter, which is binding on all States. Both the ICTY and ICTR were created under Chapter VII of the Charter.

167 Statute of the International Criminal Tribunal for the Former Yugoslavia, as amended 30 November 2000 by Resolution 1329 [ICTY Statute] <http://www.un.org/icty/basic/statut/stat2000_con.htm> (last accessed 16 August 2001). Art 1; Statute of the International Criminal Tribunal for Rwanda, Article 3 [ICTR Statute] $<\mathrm{http}: / /$ www.ictr.org/ENGLISH/basicdocs/statute.html> (last accessed 10 August 2001) Art 1.

168 The ICC only has jurisdiction over offences from the time of the entry into force of the Statute (on 1 July 2002) ICC Statute, Under Art 126 of the Rome Statute of the International Criminal Court, 17 July 1998 (1998) 37 ILM 998 [ICC Statute], Art 11. However, for States who ratify after 1 July 2002 the court only has jurisdiction over crimes after entry into force for that State unless they make a special declaration, Art 11(2). For an offender who is a national of a State that is not a party to the Statute to come within the jurisdiction of the ICC the alleged crimes must have been committed on the territory of a State-party, or on the territory of a State that is willing to accept the jurisdiction of the ICC with respect to that offence, or the crime in question is referred to the ICC by the United Nations Security Council acting under Chapter VII of the United Nations Charter, Art 12(2)(a). There are therefore practical limitations on the jurisdiction of current international courts. 
The ICJ's decision is not a satisfactory decision from a principled perspective. Many serious international crimes have jus cogens status; they are peremptory norms of international law that States cannot derogate from. ${ }^{169}$ In the Pinochet case, Lord Brown-Wilkinson was of the opinion that breaches of jus cogens rules may be punished by any State because the offenders are the common enemy of all mankind. ${ }^{170}$ As Judge Al-Khasawneh noted in his dissenting judgment in DRC $v$ Belgium where two norms of international law come into conflict, if one of them is of a jus cogens character then that norm should prevail. He argues that this is not the effect of the majority judgment, where the non-peremptory norm of sovereign immunity for a Foreign Minister effectively trumps the jus cogens norm of criminal responsibility for serious international crimes. ${ }^{171}$ The practical impunity the ICJ decision represents for high State officials may undermine these jus cogens norms, and the principles behind the decision should be questioned on that basis.

\section{CONCLUSIONS: CRIMINAL LIABILITY UNDER INTERNATIONAL LAW?}

The issues raised in this paper are extremely topical as there are a number of conflicts currently being fought across the globe. Some, such as that in DRC, are being fought with the savagery and disregard for international humanitarian law that characterised so many of the conflicts of the last century. ${ }^{172}$ Others are being represented by the western combatants (principally the United States and United Kingdom) as being waged scrupulously within the boundaries of international humanitarian law, a characteristic of the Kosovo campaign in 1999 and the "war on terror" that so far been waged in Afghanistan. However, as noted in this paper there were numerous allegations of

169 Case concerning the Arrest Warrant of 11 April 2000 (Democratic Republic of the Congo v Belgium) (14 $\begin{array}{lll}\text { February 2002) ICJ } \quad<\text { http://www.icj- } & -\end{array}$ cij.org/icjwww/idocket/iCOBE/icobe/judgment/icobe_judgment_20020214.pdf) (last accessed 20 September 2002), para 7 where Judge Al-Khasawneh, in his dissent, states this principle is of a jus cogens character. [DRC v Belgium Al-Khasawneh Dissent]; The concept of jus cogens is included in the Vienna Convention on the Law of Treaties (1969) 1155 UNTS 331 Art 53, 64.

170 Draft Code of Crimes against the Peace and Security of Mankind 1996 Art 18 [ILC Draft Code] $<\mathrm{http} / / /$ www.un.org/law/ilc/texts/dcodefra.htm $>$ (last accessed 1 April 2001). The Draft Code was provisionally adopted in 1988: Regina v Bartle and the Commissioner of Police for the Metropolis and Others, Ex Parte Pinochet; Regina $v$ Evans and Another and the Commissioner of Police for the Metropolis and Others, Ex Parte Pinochet [1999] UKHL 17, (HL) Lord Brown-Wilkinson, paras 40 - 41.

171 Joint (separate) opinion of Judges Higgins, Kooijmans and Buergenthal in the Case Concerning the Arrest Warrant of 11 April 2000 (Democratic Republic of the Congo v Belgium) (14 February 2002) ICJ para 80 $[D R C$ v Belgium Joint Separate Opinion] <http://www.icj-cij.org/icjwww/idocket/iCOBE/icobejudgment/ icobe_ijudgment_20020214_higgins-kooijmans-buergenthal.PDF> (last accessed 20 September 2002), para 85; DRC v Belgium Al-Khasawneh Dissent, above, para 6; Dissenting Opinion of Judge Van Den Wyngaert in DRC v Belgium, para 36 [DRC v Belgium Van Den Wyngaert dissent] <http://www.icj-cij.org/ icjwww/idocket/iCOBE/icobejudgment/icobe_ijudgment_20020214_vdwyngaert.PDF> (last accessed 22 September 2002) para 7.

172 For example see the Human Rights Watch Report on the massacres in Kisangani $<$ http://hrw.org/reports/2002/drc2/> (last accessed 22 September 2002). 
war crimes from Kosovo, and there have been serious allegations relating to the war in Afghanistan, such as the allegations relating to death of hundreds of Taleban and Al-Qaeda prisoners by suffocation. ${ }^{173}$

Regardless of the justice of their cause, or lack of it, all combatants must abide by international humanitarian law. Commanders have a responsibility to prevent their soldiers from committing war crimes, or other serious international crimes, and to punish them if crimes are committed. If commanders do not do their duty in this regard they may be criminally liable for the acts of their subordinates. Civilian leaders including Heads of Government and Heads of State can be subject to this duty, and the consequent liability for failure to perform it. It is incumbent upon the leaders of States and military forces, such as President Bush and Prime Minister Blair with the "war on terror", to ensure that their military action is lawful. If they fail to take reasonable measures to fulfil this duty then they undermine the legal and moral authority of their struggle, and they should be prosecuted for their failure to meet the duties imposed on them by international law.

In the context of the Kosovo operation and the incidents discussed in this paper, it is unlikely that either Bill Clinton or Tony Blair would be liable for the offences. It is possible, applying the international law tests, for them to be liable under the doctrine of command responsibility for any failure to prevent or to punish international crimes committed by their forces. However, in the first instance there is insufficient evidence to support a prosecution, as the OTP concluded, ${ }^{174}$ and without the cooperation of the United States and the United Kingdom military it is unlikely that any further evidence could be gathered. There is also the likely prospect that NATO and their respective armed forces have conducted investigations into the incidents. If these were conducted with due diligence and concluded that no offences had occurred they would be probably be sufficient to negate the mens rea required for command responsibility and to constitute necessary and reasonable measures.

Even if liability was established, there is the obstacle of sovereign immunity to overcome. Bill Clinton, as an ex-Head of State, would only be protected by immunity ratione materiae, giving him immunity only for official acts performed whilst in office. Following the reasoning in Pinochet acts that give rise to individual criminal responsibility cannot be characterised as official acts, and his immunity could not shield him from prosecution at a domestic or international level. ${ }^{175}$ If

173 UN News Centre "Afghanistan: United Nations Issues Details of Visit to Alleged Mass Grave Site" 20 August $2002<$ http://www0.un.org/apps/news/story.asp?NewsID=4510\&Cr=afghanistan $\& \mathrm{Cr} 1=>\quad$ (last accessed 22 September 2002).

174 Final Report to the Prosecutor by the Committee Established to Review the NATO Bombing Campaign Against the Federal Republic of Yugoslavia, para 90.

175 Under the third exception noted in para 61 of the ICJ judgment in Joint Separate opinion of Judges Higgins, Kooijmans and Buergenthal in the Case Concerning the Arrest Warrant of 11 April 2000 (Democratic Republic of the Congo v Belgium) (14 February 2002) ICJ para 80 [DRC v Belgium Joint Separate Opinion] 
international law is characterised by the reasoning of the ICJ, Tony Blair's status as a current Head of Government would effectively give him complete immunity from prosecution unless the United Kingdom waived his immunity or prosecuted him itself. His immunity ratione personae prevents domestic courts from extending their jurisdiction to him, even when that jurisdiction is founded in an international convention. ${ }^{176}$ Practically this prevents this assumption of jurisdiction to arrest and extradite him to an International Court that had the necessary jurisdiction to overcome his immunity and to try him. ${ }^{177}$ The result is a virtual impunity for Blair.

The limitations on jurisdiction of current international courts, combined with the reasoning of the ICJ in the DRC v Belgium case undermine the principle of individual criminal responsibility. Those guilty of crimes of a jus cogens nature are shielded by an immunity that for all practical purposes equals impunity. This paper submits that this is not a satisfactory interpretation of international law, and if this in fact a correct interpretation it needs to be challenged by States to effect a change to the international customary law. Domestic courts can be an appropriate forum, and in some cases may be the only forum to answer breaches of jus cogens norms that by definition are of fundamental concern to all States.

$<$ http://www.icj-cij.org/icjwww/idocket/iCOBE/icobejudgment/icobe_ijudgment_20020214_higginskooijmans-buergenthal.PDF $>$ (last accessed 20 September 2002).

176 DRC v Belgium, above, para 59.

177 With the possible exception of the ICTY, which would have jurisdiction with respect to these offences, as that tribunal is founded by a Chapter VII resolution of the United Nations Security Council, Statute of the International Criminal Tribunal for the Former Yugoslavia, as amended 30 November 2000 by Resolution 1329 [ICTY Statute] <http://www.un.org/icty/basic/statut/stat2000_con.htm> (last accessed 16 August 2001). 